EstAg 30 (1995) 239-280

\title{
Algunas exigencias culturales de la Nueva Evangelización
}

¡La nueva evangelización! Es una bonita expresión salida hace años de la boca del actual Papa, Juan Pablo II. Pronunciada por primera vez en un país de América española y mirando a la celebración del V Centenario del Descubrimiento, encontró muy pronto un horizonte más amplio, al contemplar el mismo Papa la des-cristianización de países tan empapados de cristianismo como la vieja Europa. El punto de mira es ahora el año 2000, aniversario significativo, según el cómputo actual, del nacimiento de Cristo. Se trata, como se puede ver fácilmente, de una llamada urgente, que tiene muchos visos de ser una llamada bastante dramática.

Los frentes primarios de esta nueva evangelización no son ya las naciones no cristianas. Son las naciones en otro tiempo llamadas cristianas y que están sufriendo los embates de una cultura que ha dejado de ser cristiana, por el hecho de haber dejado de ser religiosa. Como si religión y cultura estuvieran condenadas a no entenderse. Incluso, a excluirse.

$\mathrm{El}$ hecho es grave. Y es interpelador tanto para la cultura como para el cristianismo, en cuyo seno se ha lanzado el reto de la nueva evangelización. Una y otro deben realizar el esfuerzo necesario para superar el posible enfrentamiento y encontrar caminos de acercamiento. Al fin y al cabo, una y otro tienen la misión de servir a la persona humana y de servirla de la forma más adecuadamente posible.

Como creyente cristiano y miembro de la iglesia católico-romana, en cuyo seno ha surgido el lema de la nueva evangelización, siento la obligación de llevar a cabo una reflexión serena sobre el delicado tema de la nueva evangelización. La iglesia, que ha lanzado el lema de la nueva evangelización por boca de su máximo dirigente, es una institución secular con características muy peculiares. Ella es, ante todo y sobre todo, portadora de un mensaje religioso o, mejor, salvífico, que debe transmitir fielmente. Se le impone, pues, la fidelidad como algo inapelable. Ese mensaje, cuya acuñación más representativa y cualificada es la así llamada Sagrada Escritura, no ha caído del cielo, como si fuera un aerolito, sino que ha estado sometido a los vaive- 
nes de la historia y a la influencia de las culturas. Que es lo mismo que afirmar que el mensaje está envuelto por una serie de revestimientos culturales, que están sometidos a la precariedad de los tiempos. Y ello es aplicable tanto a la Sagrada Escritura como a las formulaciones dogmáticas hechas por la iglesia. Una y otras están sometidas a una reinterpretación que las haga más acordes con las conquistas científicas de la humanidad y así alcanzar ese nivel de competencia necesario para ser aceptadas por una mentalidad que ya no es pre-científica, como lo fue la cultura que las vio nacer, sino científica como es nuestra cultura. Todo ello se hace no por inadecuado afán científico, que lo quiera entender todo, sino por respeto a las nobles exigencias de la razón humana.

En fuerza, pues, de estos datos o modos nuevos de ver las cosas, la iglesia, que se propone llevar a cabo una nueva evangelización, debe ser consciente que pesa sobre ella la no pequeña tarea de poner al día contenidos y formulaciones de lenguaje, que han estado marcados por determinadas culturas. De no hacerlo, la nueva evangelización quedará en una bonita expresión, sin encontrar eco en el ámbito de nuestro mundo. Lo que se diga estará marcado por la cruda realidad de la esterilidad, sin encontrar la necesaria acogida. Más aún: se recibirá con disgusto y rechazo. Lo cual no hace sino confirmar lo que ya, según datos incuestionables, está sucediendo con mensajes del magisterio actual. Y ello no es ni mucho menos una buena señal.

La fidelidad, que la iglesia debe al mensaje, no puede quedar aprisionada por los grillos de una cultura envejecida. Debe ser una fidelidad viva, atenta al soplo del Espíritu Santo y en diálogo con la cultura de nuestro tiempo. Una cultura que, entre otras características, tiene la de ser dinámica y no estática. El trabajo, que presento, quiere responder a esta forma de ver las cosas. Es un campo amplio, excesivamente amplio, para los márgenes de un trabajo. Por ello, se impone la elección de algunos puntos que, por su significado, tienen carácter fundamental.

Inicio, pues, la tarea de hablar de algunas exigencias culturales, importantes por cierto, para que la nueva evangelización sintonice con la sensibilidad y la cultura de nuestro tiempo.

\section{1.- PRESENTAR EL MENSAJE CENTRAL DE LA SALVACION COMO OBRA DE AMOR Y NO DE JUSTICIA.}

Estamos en la cresta de la ola. Es decir, en el centro del mensaje cristiano. Cristo es, por encima de todo, el Redentor. Entendemos que el Papa Juan Pablo II pueda escribir en su encíclica programática Redemptor hominis estas sugestivas palabras: «El redentor del hombre, Jesucristo, es el cen- 
tro del cosmos y de la historia. A El se vuelven mi pensamiento y mi corazón en esta hora solemne que está viviendo la iglesia y la entera familia humana contemporánea. En efecto, este tiempo en el que, después del amado predecesor Juan Pablo I, Dios me ha confiado por misterioso designio el servicio universal vinculado a la cátedra de San Pedro en Roma, está ya muy cercano al año 2000... Nos estamos acercando ya a tal fecha que - aún respetando todas las correcciones debidas a la exactitud cronológica - nos hará recordar y renovar de manera particular la conciencia de la verdad-clave de la fe, expresada por San Juan al principio de su evangelio: $Y$ el Verbo se hizo carne $y$ habitó entre nosotros (Jn 1,14 ). Y en otro pasaje: Porque tanto amó Dios al mundo, que le dio su unigénito Hijo, para que todo el que crea en él no perezca, sino que tenga la vida eterna $(\mathrm{Jn} 3,16){ }^{1}$.

Insistiendo sobre el tema, Juan Pablo II escribe en su última carta-encíclica Redemptoris missio: «Remontándonos a los orígenes de la iglesia, vemos afirmado claramente que Cristo es el único Salvador de la humani$d a d$, el único en condiciones de revelar a Dios y de guiar hacia Dios. A las autoridades religiosas judías que interrogan a los apóstoles sobre la curación del tullido realizada por Pedro, éste responde: Por el nombre de Jesucristo, el Nazareno, a quien vosotros crucificasteis y a quien Dios resucitó de entre los muertos; por su nombre y no por ningún otro se presenta éste aquí delante de vosotros... Porque no hay bajo el cielo otro nombre dado a los hombres por el que nosotros debamos salvarnos (Hech 4,10.12). Esta afirmación, dirigida al Sanedrín, asume un valor universal, ya que para todos -judíos y gentiles- la salvación no puede venir más que por Jesucristo» ${ }^{2}$.

Ciertamente así suenan las cosas desde la Biblia y desde las instancias magisteriales. Mas en este momento surge una pregunta, que, por otra parte, está suscitada por los nuevos avances en el conocimiento tanto de la historia de las religiones como de sus valores reconocidos a la luz de su significado salvífico. La pregunta se formula así: ¿Se puede seguir manteniendo, sin más ni más, es decir, sin las convenientes matizaciones, el mensaje de las frases anteriores? La pregunta, así formulada, no puede recibir más que una respuesta negativa. Las religiones no cristianas reciben hoy un reconocimiento salvífico que se les fue negado en el pasado. Hoy nadie se atrevería a afirmar que fuera del nombre de Jesús, así como suena, no hay salvación posible para el hombre. Los caminos de salvación, ofrecidos por Dios al hombre, desbordan los cauces del mensaje cristiano. Y se entiende con facilidad. Más de las tres cuartas partes de la humanidad desconocen a Cristo. Lo que,

1. Juan Pablo II. RH. 1.

2. Juan Pablo II. RM. 5,14a. 
según el presupuesto anteriormente formulado, supondría que más de las tres cuartas partes de la humanidad estarían fuera del horizonte salvífico. Si esto fuera así, habría que cuestionar muy seriamente la voluntad universal salvífica de Dios.

Todo ello nos lleva como de la mano a una formulación nueva del problema de la salvación del hombre, que, en definitiva, es lo que está en juego en todas las religiones. Todas las religiones son, de una forma o de otra, caminos de salvación para quienes las profesan. Esta nueva forma de ver las cosas, este nuevo estilo de presentar el tema de la salvación ha encontrado eco en los mensajes del concilio Vaticano II. «La iglesia no rechaza nada de lo que en estas religiones hay de santo y verdadero. Considera con sincero respeto los modos de obrar y de vivir, los preceptos y doctrinas, que, por más que discrepen en mucho de lo que ella profesa y enseña, no pocas veces reflejan un destello de aquella Verdad que ilumina a todos los hombres. Anuncia y tiene la obligación de anunciar a Cristo, que es el camino, la verdad y la vida (Jn 14,6), en quien los hombres encuentran la plenitud de la vida religiosa y en quien Dios reconcilió consigo todas las cosas (cf. 2 Cor 5, 18-19).

Por consiguiente, exhorta a sus hijos a que, con prudencia y caridad, mediante el diálogo y la colaboración con los adeptos de otras religiones, dando testimonio de la fe y la vida cristiana, reconozcan, guarden y promuevan aquellos bienes espirituales y morales, así como los valores socio-culturales que en ellos existen ${ }^{3}$.

Hechas estas matizaciones, y retomando el mensaje de Juan Pablo II, es oportuno ahora recordar algunas afirmaciones de la Teología ecuménica. La Comisión evangélico-luterana/católico- romana elaboró años atrás un documento de gran valor teológico titulado El Evangelio y la Iglesia. En ese documento se aborda la cuestión de descubrir cuál es el centro del evangelio (Mitte, en lenguaje alemán), cosa que agrada especialmente a los evangélicos, mientras los católicos se inclinan más bien por una jerarquía de verdades, cuando se refieren al tema en cuestión. Pues bien, sobre el tema encontramos esta espléndida declaración: «El esfuerzo hecho para mantener la única verdad permanente entre el pluralismo de las tradiciones lleva a preguntarse cuál es el fundamento y el centro del Evangelio, fundamento y centro con referencia a los cuales las múltiples y diversas declaraciones de la fe de la iglesia pueden ser consideradas como un testimonio y desarrollo. Este fundamento y este testimonio no pueden ciertamente ser aprisionados en una fórmula teológica: consisten sobre todo en el hacer escatológico de Dios

3. Concilio Vaticano II. NA. 2 b. 
obrando la salvación mediante la cruz y la resurrección de Jesús y que toda predicación tiene por intención poner de manifiesto» 4 .

Hay en este espléndido párrafo, elaborado en ambientes ecuménicos $\mathrm{y}$, por ello, desprovisto de toda carga dogmática confesional, referencias dignas de retener. Se nos dice que el centro del mensaje cristiano se halla en «el hacer escatológico de Dios, obrando la salvación mediante la cruz y la resurrección de Jesús». En ello se nos anuncia que Jesús es, por encima de todo, nuestro Salvador. Y nos dice que la salvación no es un hecho cerrado totalmente. La tensión entre el «ya y todavía no» se esconde tras las palabras del «hacer escatológico de Dios obrando la salvación mediante la cruz y la resurrección de Jesús». De ahí que la interpretación del hecho salvífico es siempre un paréntesis sin cerrar. El mismo texto lo dice, cuando nos recuerda que el hecho salvífico no puede ser aprisionado en una fórmula teológica.

Se comprende así que el misterio salvífico haya sido objeto de múltiples y diversas declaraciones a lo largo de la historia. Incluso ello se puede afirmar de las mismas Escrituras. Algunas de ellas han quedado ya fuera de combate por responder a categorías de pensamiento estrictamente místicas. La preocupación por intentar re-formular el contenido de la salvación conseguida por Jesús está así plenamente justificada. Renunciar a ello sería entender mal el plan de Dios sobre la salvación del hombre.

Uno de los caminos a seguir en esta formulación es el que queda expresado en el enunciado del apartado: presentar el misterio central de la salvación como obra de amor y no de justicia. Seguramente el concepto de justicia, presente en la interpretación paulina de la obra salvífica de Cristo, visto desde la perspectiva del derecho romano, ha deformado de forma tal su contenido que ha llegado la hora de decir no a tal interpretación. Y hay que decir no, porque una tal interpretación resulta repugnante no sólo a la mentalidad moderna, sino también injuriosa para la misma representación de Dios.

Oigamos un texto sobre el tema desgarrador. «Hay un Jesús que no acaba de convencerme: es el Jesús crucificado, mártir. Desde niños nos han dicho que había muerto por nuestros pecados. Pero esto ya no se puede soportar. Es algo que nos desborda. Nos han mostrado a un Jesús, un hombre inocente, que paga por los demás; paga, se trata de una deuda; y ¿a quién paga? A Dios. Se trata de un padre enérgico, que exige la muerte de su hijo, la castración... Y Dios saca una doble ganancia del Gólgota: se ve finalmente satisfecho en sus sentimientos de padre ofendido y pone a los hombres, sus hijos, en un estado de inferioridad para siempre respecto a él:

4. Comisión evangélico-luterana/católico-romana. El evangelio y la iglesia. nr. 24. 
que Cristo haya muerto de ese modo, por voluntad del Padre, condena a los hombres, nos condena a nosotros, bien a obedecerle ciegamente, bien a vernos absolutamente culpabilizados, o incluso a las dos cosas a la vez» 5 .

La interpretación de la salvación como obra de justicia ha tenido, entre otros, un actor de primera línea: Anselmo. Su pensamiento en el tema alcanzó tal influencia que prácticamente canalizó toda la reflexión teológica católica. Anselmo escribe un libro famoso, si los hay, cuyo título es toda una revelación: Cur Deus homo. ¿Por qué Dios tiene que hacerse hombre? De este libro escribe el teólogo Sesboüé: «Si ningún libro ha ejercido tanta influencia en la doctrina de la redención en Occidente como el Cur Deus homo (¿por qué Dios se tiene que hacer hombre?) de San Anselmo, tampoco hay ningún teólogo de la tradición que sea un signo tan grande de contradicción. Se puede hablar de un proceso intentado contra San Anselmo, después de las críticas de V. Aulen, en el que acusadores y defensores se cruzan sus argumentos» 6 .

Según indica el título ¿Por qué Dios tiene que hacerse hombre?, Anselmo intenta dar una respuesta al interrogante propuesto. Es una respuesta racional, es decir, que intenta satisfacer a interrogantes que puedan surgir sobre el tema. En nuestro caso, una respuesta que dé razón del hecho de la encarnación del Hijo de Dios. Al articular su respuesta, Anselmo se mueve por el sendero que habían seguido la mayoría de los Padres de la Iglesia. «Si el hombre no hubiese perecido, dice Agustín, el Hijo del hombre no hubiera venido. Porque había perecido el hombre, vino Dios hombre, y se encontró siendo hombre. Había perecido el hombre en fuerza a su libre voluntad, vino Dios hombre en razón de su gracia liberadora». El dato encuentra eco muy subido en el llamado Pregón Pascual: «iOh feliz culpa -dice la iglesia llena de alborozo- que nos mereció tal y tan grande Redentor!». La plasticidad del mensaje es tal que sólo una situación sentimental puede llegar a calificar de feliz una culpa que traía entre sus brazos el alejamiento del hombre en relación a Dios y, como derivación, 'un cúmulo de males.

San Anselmo acepta este presupuesto e intenta dar una respuesta en el libro antes citado. Respuesta que estará inficionada de un marcado mal juridicista. «Lo que domina en esta teoría de la redención, dice el teólogo Hans Küng, no es la gracia, la misericordia y el amor, como en el Nuevo Testamento, sino, como en el derecho romano, una justicia concebida muy a lo humano (justitia commutativa) e incluso la lógica del derecho. En razón de esta lógica la muerte de cruz queda aislada del mensaje y la vida de Jesús al

5. SIX. J. F. Refus differénts de Jesús-Christ: Unité des Chrétiens 15(1974), 21.

6. SESBOUE. B., Jesucristo el único mediador. Ed. Secretariado trinitario, Salamanca, 1990, 353. 
mismo tiempo que de su resurrección: Jesús, en el fondo, vino para morir. El anuncio concreto, la actitud, el sufrimiento y la nueva vida del Jesús de Nazaret proyecta un mortal "juego de sombras chinescas entre el Padre y el Hijo", desarrollado según los cánones jurídicos; más aún, una pugna mortal entre la naturaleza divina y la naturaleza humana del Hijo. Y, a la vez, los hombres concretos, a quienes todo esto debe servir, desaparecen tras el Hijo de Dios casi por completo, no son interiormente afectados, ni, sobre todo, consolados en orden a la vida del más allá» 7 .

Toca ahora exponer, aunque sea brevemente, el pensamiento de Anselmo sobre la redención. Lo voy a hacer en cuatro tiempos, siguiendo la exposición magistral de Sesboüé.

\section{1.- Primer tiempo: todo debe ir seguido de una satisfacción o de una pena.}

Este principio general del derecho sugiere a Anselmo algunas reflexiones sobre el tema de la redención. Anselmo hace un análisis del pecado, presupuesto necesario para la redención según categorías del honor ofendido, violado y robado. Se entiende perfectamente desde la perspectiva descrita que el pecado tenga una malicia infinita, por aquello de que la ofensa se mide por la categoría del ofendido. En el caso, Dios.

Con ello se deja bien a las claras que quien repare la ofensa infinita tiene que poseer una categoría divina, pues sólo Dios tiene capacidad de hacer algo que tenga valor infinito. Aprovechando Anselmo el concepto de pecado como robo del honor de Dios, y siempre en la línea del derecho, dice: «El que no da a Dios este honor debido, quita a Dios lo que es suyo y le deshonra; y esto es precisamente el pecado. Y, mientras no devuelva lo que ha quitado, permanece en la culpa. Ni basta el que pague sólo lo que ha quitado, sino que, a causa de la injuria inferida, debe devolver más de lo que quitó» ${ }^{8}$.

Al texto original de Anselmo añade Sesboüé el comentario siguiente: «El análisis se basa en una transferencia analógica entre el orden de la justicia en el mundo y el orden de la justicia divina, que exige la supresión del desorden causado por el pecado. La vuelta al orden exige por tanto que Dios reciba satisfacción del pecador, o bien, si éste se niega, que sea castigado. Dios recobrará así su honor de grado o por fuerza. Porque ni él puede perderlo, ni el hombre puede escaparse de Dios: o bien se someterá a Dios en la obediencia, o bien será puesto bajo su voluntad que castiga. Al final de estas reflexiones interviene la fórmula conocida: "es necesario que a todo pecado le siga la satisfacción o la pena"» 9 .

7. S. AGUSTIN. S. 174, 2,2; ML 38, 940.

8. KUNG. H., Ser cristiano. Ed. Cristiandad, Madrid, 1977, 538.

9. SESBOUE. B., Jesucristo, el único Mediador. Sec. trinitario, Salamanca, 1990, 357. 
Segundo tiempo: El hombre pecador es radicalmente incapaz de satisfacer.

Aquí está el centro de la cuestión planteada. Y Anselmo no duda en enfrentarse con el mismo, para decirnos sin tapujos que el hombre pecador no puede satisfacer por sí mismo. Formula, de entrada, dos principios. «Tampoco, dice a Bossón su interlocutor, dudarás, creo yo, de que la satisfacción debe estar en proporción del pecado» ${ }^{10}$. $\mathrm{Y}$, para que no quede duda sobre el tema, eso tiene que ser así, porque Dios lo quiere. «Es evidente que Dios exige la satisfacción según la gravedad del pecado» ${ }^{11}$. Incapacidad del hombre para dar la satisfacción y voluntad de Dios pidiendo satisfacción, sólo pueden conjugarse en la praxis, acudiendo a un tercero. A un Mediador, que no puede ser más que el Hijo de Dios hecho hombre. Pero, antes de llegar aquí, es necesario recoger la razón que fuerza a Anselmo a decir que el hombre es incapaz de ofrecer por sí mismo la satisfacción debida por el pecado. Tras una serie de reflexiones, Anselmo viene a decir «que el hombre no puede satisfacer, porque ha sido concebido y ha nacido en pecado como consecuencia del primer pecado» ${ }^{12}$. El hombre pudo pecar y pecó . Pero el hombre no puede salir del pecado por sí mismo o apoyado en sus fuerzas. «Esta reflexión constituye un retorno a la perspectiva patrística: el hombre es parecido a uno que, a pesar de las advertencias, hubiera caído en una profunda fosa y no pudiera ya salir de ella. La segunda razón está de hecho ordenada a la primera. Anselmo vuelve a orientar según la perspectiva de la satisfacción el antiguo dato doctrinal: el hombre caído en el pecado no puede encontrar la salvación por sus propias fuerzas» ${ }^{13}$.

Tercer tiempo: la satisfacción es necesaria para completar el designio de Dios sobre el hombre.

Establecido el principio que el hombre pecador es radicalmente incapaz de satisfacer, Anselmo se enfrenta con el problema de que la satisfacción es necesaria, para que se lleve a efecto el plan primitivo de Dios sobre el hombre. La argumentación, que aplica, es muy sencilla. Sigue al pie de la letra lo que la teología de entonces decía sobre la situación del hombre antes y después de la caída. Antes de la caída el hombre estaba libre de la muerte y sus acompañantes (dolor, enfermedad) y destinado a la vida eterna, sin pasar por la muerte. Todo este plan había quedado sin efecto por el pecado del

10. S. ANSELMO. Cur Deus homo?. 1,20.

11. S. ANSELMO. Ib. I,21.

12. S. ANSELMO. Ib. I,22.

13. SESBOUE. B., Jesucristo, el único Mediador. Secr. trinitario, Salamanca, 1990, 358. 
hombre. Si no se corrige el defecto y ello sólo es alcanzable en base a una satisfacción adecuada, el plan de Dios sobre el hombre fracasaría. Tal hipótesis, posible ciertamente, no entra en los planes salvíficos de Dios. Se impone, por ello, la satisfacción adecuada, para que el designio de Dios sobre el hombre no quede anulado por el pecado del mismo. Anselmo es claro en el tema que nos ocupa. Oigamos sus propias palabras: «De aquí es fácil colegir o que Dios completará en la naturaleza humana lo que empezó o que en vano destinó tan elevada naturaleza a tan gran bien. Pero, si se reconoce que Dios no hizo cosa más grande que elevar a la naturaleza humana hasta la posesión de sí mismo, muy impropio es de él el permitir que perezca cualquier ser dotado de la naturaleza humana...

Es, pues, necesario que complete en la naturaleza humana lo que ha empezado; pero esto no se puede hacer, como dijimos, sino por la perfecta satisfacción del pecado, lo que ningún pecador puede realizar» ${ }^{14}$.

Cuarto tiempo: sólo Dios puede cumplir la satisfacción que salva al hombre.

Es la consecuencia lógica, si se tienen en cuenta los presupuestos que Anselmo usa a la hora de hablar del tema. Oigamos su argumentación: «Esto no puede realizarse más que dando a Dios por el pecado del hombre algo mayor que todo lo que existe fuera de Dios...

Es también conveniente que aquél que pueda ofrecer a Dios algo superior a todo lo que está debajo de Dios, sea mayor que todo lo que no es Dios...

Pero no hay nada que está por encima de lo que no es Dios más que Dios mismo...

Y nadie puede dar esta satisfacción más que Dios mismo...

Pero es que no debe hacerla más que un hombre, de lo contrario no satisface el hombre...

$\mathrm{Si}$, pues, como se ha demostrado, es necesario que la ciudad celestial se complete con hombres, y esto no puede hacerse más que por la dicha satisfacción, que no puede dar más que Dios, ni debe darla más que el hombre, síguese que ha de darla necesariamente un hombre Dios» ${ }^{15}$.

Anselmo ha llegado al punto que, desde el principio, se había fijado. Con ello da respuesta al título del tratado: Cur Deus homo. Dios se ha hecho hombre para poder ofrecer a Dios la satisfacción que el pecado del hombre exigía y, de este modo, conseguir que el plan primitivo de Dios sobre el hom-

14. S. ANSELMO. O. Cit. I, 2, IV.

15. S. ANSELMO. O. Cit. I, 2, VI. 
bre siguiera en pie y lograra la meta prevista. «A partir de esta conclusión, Anselmo deduce la encarnación, es decir, recobra la coherencia de los datos nuevos de la cristología tradicional. Lo mismo que los Padres habían construido esta cristología con ayuda del argumento soteriológico, también Anselmo muestra, a partir de esta nueva forma de exigencia soteriológica, la necesidad de las dos naturalezas en Cristo y de la unidad de su persona, dentro de una perspectiva muy calcedoniana. Con este mismo espíritu deduce la alta conveniencia de la concepción original y analiza el valor ante Dios de la muerte de Jesús. Cristo es sin pecado y, por tanto, no está sometido a la ley de la muerte, que no afecta al hombre más que en virtud de su pecado. Pero, si Cristo no está sometido a la muerte, puede morir, si lo quiere, voluntariamente. De esta situación es de donde nace su capacidad para satisfacer: por una parte, puede ofrecer a Dios algo mayor que todo lo que no sea Dios y, por otra, puede hacerlo sin que sea una cosa exigida y debida» ${ }^{16}$.

Se han expuesto los puntos de vista de Anselmo sobre el tema de la redención. Y se ha hecho básicamente, porque esos puntos de vista se constituyeron en herencia intocable para la posterior reflexión teológica en Occidente. La redención, y todo lo que se mueve a su alrededor, se presentó en la línea anselmiana. Hoy la respuesta anselmiana al tena no sólo no resulta convincente, sino que hasta se considera incompatible con lo más significativo de la revelación. Más aún: ofrece una imagen de Dios francamente repugnante. Se han citado algunos textos crudos en contra de esta forma de ver las cosas relativas a la redención. Oigamos ahora a uno de la casa, al teólogo F. Varone: «La satisfacción deforma el rostro de Dios, haciendo de él un monstruo o una máquina jurídica. En su último libro, L'Affaire de Jésus, Henri Guillemin enumera tres obstáculos que el cristianismo tradicional habría opuesto al mensaje de Jesús y, entre esos tres obstáculos, cita la teoría de la satisfacción, cuya descripción subraya perfectamente el desastroso efecto producido en el rostro de Dios: "sólo una víctima perfecta, -es decir, divina-, podía compensar lo infinito de la deuda. El Hijo, como había sido previsto en los planes de Yahveh, iba a ser matado por los hombres, por más que éstos añadieran a su primera falta de indisciplina otra de muy distinta gravedad: un homicidio. Pero ¿qué importa, si quedan salvados, gracias a la heroica sustitución por un inocente que carga sobre sus hombros con la culpa general? El precio del rescate debía ser inexorablemente pagado a ese dios contable e incapaz de perdonar. El asunto ha quedado cerrado y los cielos han quedado nuevamente abiertos a la posteridad de Adán"»"17.

16. SESBOUE. B., O. Cit. 359-360.

17. VARONE. F., El Dios sádico. ¿Ama Dios el sufrimiento? Sal Terrae, Santander, 1988, $17-18$. 
«La "satisfacción" reduce a Jesús al papel de víctima expiatoria, privándolo de toda densidad histórica, que es la única que da sentido y virtud salvífica a su muerte. Sus obras y sus enseñanzas no sirven, en el fondo, sino para excitar aún más al verdugo...

La tesis negativa de este libro no es, pues, una exageración, sino que es realmente fruto de mis análisis y de mi manera de sentir: La "satisfacción" es al cristianismo lo que el triángulo de las Bermudas a la navegación; y es en este espacio mortalmente devastador donde el cristianismo se hunde en la religión» ${ }^{18}$.

El texto citado es crudo y bien se puede ver al fondo la respuesta anselmiana al tema de la redención. Lo cual significa que dicha respuesta tiene sus aspectos negativos, rechazados no sólo por la sensibilidad moderna, sino también no muy acordes con la revelación. La equivocación fundamental de Anselmo estuvo en haber llevado al campo de lo jurídico una obra de amor. Esto es lo que hay que recuperar y así hay que presentar el tema de la redención. Se impone, pues, el cambio de horizonte ideológico. Sólo desde el amor de Dios, que no tiene que ver nada con el concepto de satisfacción, se puede entender en la fe la obra llevada a cabo por Cristo en favor del hombre.

En confirmación de lo que estoy diciendo es necesario traer aquí el famoso y hermoso texto del evangelio de Juan: Tanto amó Dios al mundo, que no dudó en entregarle su Hijo único, para que todo el que crea en él no perezca, sino que tenga la vida eterna. Pues no envió Dios a su Hijo para dictar sentencia de condenación contra el mundo, sino para que por medio de él se salve el mundo (Jn 3,16-17).

La redención, que tiene como finalidad suprema la vida eterna, es, por tanto, secuencia del amor de Dios. Y el amor no entiende de matemáticas, ni las exige. No es un do ut des. Me das una satisfacción y te perdono. Es simplemente un $d o$ sin retorno. Sin contrapartida. Un do que llega hasta el límite, que no es otro que hacerse en todo semejante al amado. Dios-Padre, por medio de su Hijo, que se hace hombre, se ha acercado al hombre sin límites y ha aceptado la condición humana en todos sus aspectos, excepto en el pecado. Del Hijo de Dios, hecho hombre, afirma la carta a los Hebreos: Pues no es él un sacerdote incapaz de compadecerse de nuestras debilidades; todo lo contrario, ya que, excepto en el pecado, ha pasado por la mismas pruebas que nosotros $(4,15)$.

El Hijo de Dios, al hacerse hombre en la plenitud de los tiempos, se ha sometido a la muerte, al igual que todo hombre tiene que someterse a ella por el simple hecho de ser hombre. Morir es consubstancial a la condición

18. VARONE. F., O. Cit. 91-92. 
humana. El hecho de morir para Jesús se sitúa en la misma línea que el de cualquier hombre. Otra cosa es el género de muerte que sufrió. La muerte en la cruz no es un hecho pre-establecido, como tantas veces se ha dicho.

Pensar así es quitar a la muerte de Jesús su sentido y colocarla bajo el signo de lo mágico. El estilo de muerte de Jesús no es, por tanto, un hecho $a$ priori. Es un hecho a posteriori. La muerte en cruz es una consecuencia de la opción hecha por Jesús en fidelidad a su misión. Jesús podía haber evitado la muerte en cruz. Hubiera sido suficiente para ello haber claudicado en su misión. Por tanto, si tuvo que padecer la muerte de cruz, fue porque su persona y su mensaje no se plegaron a los poderes religiosos y civiles de su tiempo. En pocas palabras, porque denunció sin tapujos todo aquello que, bajo diverso ropaje, se hacía para esclavizar al hombre. La muerte de cruz fue, en definitiva, consecuencia de la injusticia humana más que designio pre-establecido de Dios. La persona de Jesús, y lo que decía y hacía, no encajaban en el esquema de una sociedad construida sobre el atropello de los derechos humanos y la injusticia. «La muerte, dice F. Varone, será necesaria, y Jesús es lo bastante lúcido para saberlo y decírselo a sus amigos. Pero no se trata de una necesidad derivada de un trágico contrato, ni se trata tampoco de una fatal exigencia del dios de los sacrificios. Se trata de una necesidad histórica, no trascendental ni eterna, de dar testimonio de la verdad (Jn 18,37) hasta el final y al precio que sea. El contexto en que Juan nos hace saber esta última motivación de Jesús frente a la muerte es un contexto sumamente significativo: Jesús está negando los subversivos proyectos de realeza de los que el poder religioso -con habilidad, pero también con perfidia- le acusa ante Pilato. No será posible ocultar la verdad: no es la búsqueda del poder lo que precipita a Jesús a la muerte, sino su praxis diferente, con la que revela las mentiras del poder, a la vez que revela también a ese Dios diferente del segregado y utilizado por el poder religioso» ${ }^{19}$.

El signo de esta muerte, a primera vista catastrófico y sin esperanza, cambió de sentido a causa de la resurrección. La resurrección del Hijo por el Padre convirtió la muerte de Jesús en la cruz en fuente de vida para los hombres. Estos no tienen que ofrecer nada como contrapartida. Lo único que tienen que hacer es aceptar el dinamismo del amor. Que no es otro que acoger el don de Dios. Abrirse al don de Dios. Ello acontece por la fe. Seguramente que ahora nos queda más fácil entender lo que Pablo afirma sobre la justificación: Estamos convencidos, sin embargo, que Dios restablece en su amistad al hombre por medio de la fe en Cristo Jesús y no por el mero cumplimiento de la ley (Gál 2,16a). Vistas así las cosas, no hay nada que resulte humillante para el hombre e indecoroso para Dios. Dios es fiel a su misma condición de ser AMOR y al hombre se le respeta su capacidad de cerrarse al don de Dios.

19. O. Cit. $91-92$. 
En fuerza del amor, motor de la encarnación y de la redención, se alcanza a comprender frases y conductas que no sería posible desde otra perspectiva y que revelan actitudes fundamentales de Jesús. Alcanza uno a comprender, por ejemplo, que Mateo aplique a Jesús una frase del DeuteroIsaías y que lo haga después de narrarnos una jornada agotadora en favor de los necesitados. Con ello indica el evangelista hasta dónde llega la identificación de Jesús con el hombre sufriente. Tomó sobre sí nuestras debilidades y cargó con nuestras enfermedades $(3,17 \mathrm{~b})$. Movido del amor al hombre, Jesús hace realidad en su vida lo que él presentó a sus discípulos como la mayor prueba de amor: morir por el amigo. El amor supremo consiste en dar la vida por los amigos (Jn 15,13). Y, si recordamos el mensaje paulino, todavía tenemos que dar un paso adelante. Un paso, por cierto, sorprendente. Incapaces como éramos de salvarnos, Cristo, en el momento oportuno, murió por los culpables. Difícil cosa es afrontar la muerte, aunque sea en favor de una persona buena; no obstante, por una persona buena de verdad, tal vez alguien estaría dispuesto a morir. Pues bien, Cristo murió por nosotros, que éramos pecadores: ¿puede haber prueba mayor del amor que Dios nos tiene? (Rom 5,6-8).

Siguiendo en la línea de inspiración paulina, no se puede pasar por alto uno de los textos más espléndidos sobre el tema. Se trata de un texto precioso de la carta a los Efesios, carta que pertenece al corpus paulinum. "Pero la piedad de Dios es grande e inmenso su amor hacia nosotros. Muertos como estábamos en razón de nuestras culpas, Dios nos hizo revivir a una con Cristo -jvuestra salvación es pura generosidad de Dios!-. Nos resucitó y nos sentó con Cristo Jesús en el cielo. Desplegó así, ante los siglos venideros, toda la riqueza impresionante de su gracia, hecha bondad para nosotros en Cristo Jesús. La bondad de Dios os ha salvado, en efecto, mediante la fe. Y eso no es algo que provenga de nosotros; es un don de Dios. No es, pues, cuestión de obras humanas, para que nadie pueda presumir. Lo que somos, a Dios se lo debemos" (Ef 2,4-9).

Espléndido texto que desprende un chorro intenso de luz sobre el sentido de la redención. Una redención que hunde sus raíces en el amor sin contrapartida por parte del hombre. Es el mejor regalo, sin duda, para el hombre que, a pesar de sus conquistas técnicas, siente que su corazón tiene aspiraciones que nada de eso puede llenar. El Dios y Padre de nuestro Señor Jesucristo ha salido al encuentro el hombre, para ofrecerle su amor y su bondad y su vida. En su ser y en su hacer el hombre, que se abre al don de la gracia, puede encontrar respuesta para los acuciantes interrogantes de su vida. Seguramente que encuentran aquí eco especial las hermosas palabras 
de Agustín al principio de sus Confesiones: «Nos hiciste, Señor, para Ti y nuestro corazón está inquieto hasta que descanse en $\mathrm{Ti}{ }^{20}$.

En perfecta sintonía con lo que acabo de recordar Juan Pablo II escribe en su última carta-encíclica lo siguiente: «El anuncio tiene prioridad permanente en la misión: la iglesia no puede sustraerse al mandato explícito de Cristo; no puede privar a los hombres de la Buena noticia de que son amados y salvados por Dios. La evangelización también debe contener siemprecomo base, centro y a la vez culmen de su dinamismo una clara proclamación de que en Jesucristo se ofrece la salvación a todos los hombres, como don de la gracia y de la misericordia de Dios (EN.27). Todas las formas de la actividad misionera están orientadas hacia esta proclamación que revela e introduce el misterio escondido en los siglos y revelado en Cristo. (cf. Ef 3,39; Col 1,25-29), el cual es el centro de la misión y de la vida de la iglesia, como base de toda evangelización» ${ }^{21}$.

\section{2.- VALORAR LAS DEMAS RELIGIONES COMO CAMINOS DE SALVACION Y CONTEMPLAR LA REALIDAD DE LA MISION DE LA IGLESIA EN ESTE CONTEXTO.}

Estamos ante un punto nuevo en el tema de la evangelización. Un punto que supone un quiebro en el tema, hasta el extremo que hoy ya no se puede mantener el mismo paradigma que ha servido de base al tema de la evangelización. Las mismas palabras de Juan Pablo II, antes citadas, por demás recientes, padecen la influencia de una visión del texto bíblico hoy insostenible. Ciertamente, según la versión mateana del tema, el recién resucitado se aparece a los Once en Galilea y les manda ir por todo el mundo, predicar el evangelio a toda criatura y hacer discípulos suyos de todos los pueblos. Con todo, y a pesar de la rotundidad del texto, hoy ya no se puede interpretar como se ha hecho tradicionalmente, apoyando un estilo de misión que imponga, por así decirlo, el mensaje de Jesús con carácter absoluto. El nuevo mapa religioso pide otra interpretación. El tema es delicado, ciertamente. Mas los nuevos avances en el estudio de las religiones impone la tarea de superar las simples formulaciones pasadas y ofertar nuevas concreciones del tema de la evangelización. El cristianismo ya no puede seguir manteniendo un clima de superioridad frente a las demás religiones, hasta el extremo de querer presentarse como el único camino de salvación. Ha llegado la hora del diálogo y no de la imposición. Como el tema es delicado, voy a tratarlo

20. S. AGUSTIN. Confesiones. I,1,1.

21. JUAN PABLO II. RM. 44, 69-70. 
con sumo cuidado. Eso sí: superando posturas preestablecidas en favor de algunas manifestacionies concretas religiosas.

Comienzo por un texto programático: «Hoy podemos partir de que la religión es consubstancial a la naturaleza humana originaria $y$, por consiguiente, duradera para siempre. Nunca ha habido un "ser-hombre-en sí" al que luego se le añadiera, por algún motivo, como complemento, lo religioso. El origen de la religión coincide con el origen del hombre, por lo cual cabe esperar que pervivirá mientras perviva la naturaleza humana...

Esto lo han reconocido, sobre todo, los grandes historiadores de la religión. Por eso, pudo decir Mircea Eliade $(1973,10)$ que es sin duda el hombre que, en conjunto, tiene una visión más amplia de las manifestaciones religiosas de la humanidad: "Ser hombre o, mejor, devenir hombre significa ser religioso"» ${ }^{22}$.

Reconocido el hecho religioso como algo sustancial al hombre, abordo ahora el tema central de toda forma de creencia religiosa. ¿Cuál es el tema? No es otro que la salvación. Todas las religiones se ofrecen al hombre como camino de salvación. La vida del hombre, por más logros técnicos conseguidos, se ve amenazada por una serie de inconvenientes que tocan lo más profundo del ser humano. He aquí los más significativos: el dolor, la enfermedad, el desorden moral, la muerte. Nada de esto ha desaparecido del horizonte humano. Por ello, el hombre se pregunta y lo hace hasta con angustia: «¿Qué es el hombre? ¿Cuál es el sentido del dolor, del mal de la muerte, que, a pesar de tantos progresos hechos, subsisten todavía?... ¿Qué hay después de esta vida temporal?» ${ }^{23}$.

Todas las religiones, con tonalidades diversas y música de fondo común, se esfuerzan por dar respuesta a esos graves e insoslayables interrogantes que el hombre tiene ante sí. Creo que se alcanza a ver ahora con cierta facilidad por qué lo religioso significa tanto para el hombre. Al fin y al cabo, lo religioso hunde sus raíces en lo más profundo del ser humano. En este contexto el concilio Vaticano II dibuja con palabras espléndidas la misión de la iglesia y de la fe que la configura como comunidad religiosa. «Cree la iglesia que Cristo, muerto y resucitado por todos, da al hombre su luz y su fuerza por el Espíritu Santo, a fin de que pueda responder a su máxima vocación, que no ha sido dado bajo el cielo a la humanidad otro nombre en el que puedan los hombres alcanzar la salvación. Igualmente cree que la clave, el centro y el fin de toda la historia humana se hallan en su Señor y Maestro. Afir-

22. WELTE. B., Cristianismo y religiones del mundo. En Fe cristiana y sociedad moderna. Ed. SM. Madrid, 1989, 61.

23. CONCILIO VATICANO II. Gaudium et Spes. 10a. 
ma además la iglesia que bajo la superficie de lo cambiante hay muchas cosas permanentes, que tienen su último fundamento en Cristo, que existe ayer, hoy y para siempre. Bajo la luz de Cristo, imagen de Dios invisible, primogénito de toda la creación, el concilio habla a todos para esclarecer el misterio del hombre y para cooperar en el hallazgo de soluciones que respondan a los principales problemas de nuestra época» ${ }^{24}$.

La misión de la iglesia ha sido, es y será, y así lo recuerda el concilio Vaticano II, anunciar a Cristo y lo que se mueve alrededor de su persona como camino de salvación. Incluso, y puestas todas las salvedades posibles, como único camino de salvación. Ningún otro puede salvarnos, pues en la tierra no existe ninguna otra persona a quien Dios haya constituido autor de salvación (Hech 4,12). «La iglesia, enviada por Dios a las gentes para ser "sacramento universal de salvación", por exigencias íntimas de su catolicidad y obedeciendo al mandato de su Fundador (cf. Mc 16,16), se esfuerza en anunciar el Evangelio a todos los hombres. Porque los apóstoles mismos, en quienes está fundada la iglesia, siguiendo las huellas de Cristo, predicaron la palabra de la verdad y engendraron las iglesias. Obligación de sus sucesores es dar perennidad a esta obra, para que la palabra de Dios sea difundida y glorificada y se anuncie y establezca el reino de. Dios en toda la tierra (2 Tes $3,1) »{ }^{25}$. La iglesia no puede olvidar el cumplimiento de la misión encomendada. De hacerlo, dejaría de ser la iglesia de Cristo. La iglesia vive para la misión. Debe vivir, al menos. En ello está su razón de ser.

A la hora de llevar a cabo su cometido, la iglesia ha seguido modos diversos. Durante mucho tiempo su actuación apostólica estuvo impulsada por un principio eclesiológico, que respondía rígidamente a una forma absolutista de ver su misión. Tal principio se formulaba así: «fuera de la iglesia no hay salvación». Oigamos un texto del gran maestro Agustín: «Fuera de la iglesia católica se puede alcanzar todo menos la salvación. Puede haber honor, puede haber sacramento, puede cantarse el Aleluya, se puede responder amén, puede existir el evangelio, puede darse la fe en el Padre y el Hijo y el Espíritu Santo y puede ser predicada; pero sólo en la iglesia católica puede encontrarse la salvación» ${ }^{26}$. El famoso principio se tomó tan a la letra que resultaba normal ver la misión de la iglesia conseguir que todos los hombres llegaran a formar parte de la misma, recibiendo el bautismo. Adoctrinar por encima y bautizar cuanto antes podría resumir este estilo de misión.

24. Ib. $10 \mathrm{~b}$.

25. CONCILIO VATICANO II. Ad Gentes. 1a.

26. SAN AGUSTIN. S. Ad Caesar. Eccl. pleb. 6; ML 43, 695. 
Un ejemplo elocuente de este estilo de misión fue la actuación misionera durante el siglo XVI y siguientes. Acción misionera que ha sido, sin lugar a dudas, la más fructífera tras la llevada a cabo en los orígines. Es significativo al respecto el contenido de la famosa carta que S. Francisco Javier, el más grande de los misioneros, dirige desde el extremo oriente a S. Ignacio de Loyola. «En estos lugares, cuando llegaba, bautizaba a todos los muchachos que no eran bautizados; de manera que bauticé una gran multitud de infantes que no sabían distinguir la mano derecha de la izquierda» ${ }^{27}$.

El tiempo y la reflexión descubrieron las limitaciones del adagio teológico en cuestión. ¿Cómo seguir manteniendo sin más «fuera de la iglesia no hay salvación», cuando la mayor parte de la humanidad está de hecho fuera de la iglesia? Ello suponía un atentado de lesa majestad contra la universalidad de la salvación acaecida en Cristo y de la que la iglesia es sólo sacramento, y sacramento no único. Para solventar los inconvenientes que llevaba consigo una tal interpretación, ahora a todas luces excesivamente rígida, se pensó en dar un cierto giro al principio. Un principio que se consideraba todavía intocable. Se habló entonces de una pertenencia al alma de la iglesia. Todos los que no pertenecían a la iglesia como tal, podían pertenecer al alma de la iglesia. Para lo que bastaba sin más seguir los postulados de la conciencia, a la hora de obrar. Quien era fiel a tales postulados se encontraba en caminos de salvación, ya que, por ello, pertenecía al alma de la iglesia.

La fórmula pareció, de momento, afortunada. Se mantenía así el principio, que lógicamente se consideraba intocable, y se abría al mismo tiempo un amplio camino de salvación para quienes desde la mirada exterior no pertenecían a la iglesia. Pronto aparecieron los inconvenientes y las incoherencias en dicha formulación. ¿Cómo se podía pertenecer al alma de la iglesia, sin pertenecer al cuerpo, pues el alma sólo actúa en el cuerpo?. Alma y cuerpo, si se tiene en cuenta la imagen de fondo, son dos realidades que se cruzan en vida y en actividad. No se puede pertenecer a una sin pertenecer a otro.

La fórmula dejó de ser adecuada, al tiempo que comenzaba ya a vislumbrarse por el oriente una nueva luz en el firmamento religioso. Todas esas formas convivían con una concepción descalificadora de cualquier creencia religiosa que no fuera la cristiana. La única religión verdadera era sin más la cristiana. Todas las demás eran erróneas sin paliativos. El horizonte en cuestión va a cambiar. Y. va a cambiar en razón de un mejor conocimiento de los demás credos y vivencias religiosos. Tales credos tienen también su verdad y pueden ser, y son de hecho, caminos de salvación para sus confesantes y

27. SAN FRANCISCO JAVIER. Cartas a San Ignacio. Breviario romano. En su fiesta, 3 de diciembre. 
practicantes. Oigamos sobre el tema un largo texto del concilio Vaticano II: «Ya desde la antigüedad, y hasta nuestros días, se encuentra en los diversos pueblos una cierta percepción de aquella fuerza misteriosa que se halla presente en la marcha de las cosas y en los acontecimientos de la vida humana, y a veces también el reconocimiento de la suma Divinidad e incluso del Padre. Esta percepción y conocimiento penetra toda su vida con un íntimo sentido religioso. Las religiones, al tomar contacto con el progreso de la cultura, se esfuerzan por responder a dichos problemas con nociones más precisas y con un lenguaje más apropiado. Así, en el hinduismo, los hombres investigan el misterio divino y lo expresan mediante la inagotable fecundidad de los mitos y con penetrantes esfuerzos de la filosofía y buscan la liberación de las angustias de nuestra condición, ya sea mediante las modalidades de la vida ascética, ya sea a través de la profunda meditación, ya sea buscando refugio en Dios con amor y confianza. En el budismo, según sus varias formas, se reconoce la insuficiencia radical de este mundo mudable y se enseña el camino por el que los hombres, con un espíritu devoto y confiado, pueden adquirir ya sea el estado de perfecta liberación, ya sea la suprema iluminación, por sus propios esfuerzos o apoyados en un auxilio superior. Así también las demás religiones, que se encuentran en el mundo, se esfuerzan por responder de varias maneras a la inquietud del corazón humano, proponiendo caminos, es decir, doctrinas, normas de vida y ritos sagrados.

La iglesia católica no rechaza nada de lo que en estas religiones hay de santo y verdadero. Considera con sincero respeto los modos de obrar y de vivir, los preceptos y doctrinas, que, por más que discrepen en mucho de lo que ella profesa y enseña, no pocas veces refleja un destello de aquella Verdad que ilumina a todos los hombres. Anuncia y tiene la obligación de anunciar constantemente a Cristo, que es el camino, la verdad y la vida (Jn 14,6), en quien los hombres encuentran la plenitud de la vida religiosa y en quien Dios reconcilió consigo todas las cosas (cf. 2 Cor 1,18-19).

Por consiguiente, exhorta a sus hijos a que, con prudencia y caridad, mediante el diálogo y la colaboración con los adeptos de otras religiones, dando testimonio de la fe y de la vida cristiana, reconozcan y promuevan aquellos bienes espirituales y morales, así como los valores socio-culturales que en ellos existen» ${ }^{28}$.

Después de escuchar este mensaje, salido de una asamblea tan representativa como es un concilio ecuménico, ya no pueden quedar dudas acerca de la postura de la iglesia católica para con las demás religiones. La actitud de esta iglesia frente a las demás religiones ya no es la apologética defensiva de

28. CONCILIO VATICANO II. NA. 2a, b, c 
tiempos pasados. Ya no es sostenible afirmar que los católicos tienen la verdad sin más y que las demás expresiones religiosas son llanamente erróneas. La iglesia católica reconoce valores y signos de salvación en otras religiones. Más aún: tales religiones son, de suyo, caminos de salvación para quienes viven responsablemente sus exigencias.

El reconocimiento de los valores salvíficos existentes fuera del tejido eclesial contribuye mucho a perfilar el nuevo rostro de la misión. La iglesia, es cierto, debe seguir anunciando el evangelio, es decir, la buena noticia de que Dios ha salvado al hombre por la persona y la obra de Jesucristo. Esto lo tiene que hacer con el mismo fervor y la misma ilusión de siempre. Como Pablo, la iglesia debe repetir: Pues de anunciar el mensaje de salvación no puedo enorgullecerme. Esto es una necesidad que se me impone, y pobre de mí si no lo anunciase (1 Cor 9,16). El concilio Vaticano II habla del tema con palabras sugestivas y con ese estilo tan cercano al corazón que le caracteriza. «La iglesia, enviada por Cristo para manifestar y comunicar la caridad de Dios a todos los hombres y pueblos, sabe que le queda por hacer todavía una labor misionera ingente. Pues los dos mil millones de hombres, cuyo número aumenta sin cesar, que se reúnen en grandes y determinados grupos con lazos estables de vida cultural, con las antiguas tradiciones religiosas, con los fuertes vínculos de las relaciones sociales, todavía nada o muy poco oyeron del evangelio; de ellos, unos siguen algunas de las grandes religiones, otros permanecen alejados del conocimiento del mismo Dios, otros niegan expresamente su existencia, incluso a veces la persiguen. La iglesia, para ofrecer a todos el misterio de la salvación y de la vida traída por Dios, debe introducirse en todos estos grupos con el mismo afecto con que Cristo se unió por su encarnación a ciertas condiciones sociales y culturales de los hombres con quienes convivió» ${ }^{29}$.

Juan Pablo II presenta el tema en su última carta-encíclica de la forma siguiente: «El Señor Jesús envió a sus apóstoles a todas las personas y pueblos y a todos los lugares de la tierra. Por medio de los apóstoles la iglesia recibió la misión universal que no conoce confines y concierne a la salvación en toda su integridad, de conformidad con la plenitud de vida que Cristo vino a traer (cf Jn 10,10); ha sido enviada para manifestar y comunicar la caridad de Dios a todos los hombres y pueblos» ${ }^{30}$.

Por coherencia con su propia naturaleza la iglesia no puede ceder nada en su fervor misionero. Vista así la urgencia del hecho, no queda otro remedio que aceptar y reconocer con agrado que la visión positiva del valor salví-

29. CONCILIO VATICANO II. Ad Gentes. 10

30. JUAN PABLO II. RM. 31a. 
fico de otras religiones no puede quedar reducido al ámbito de lo teórico. Debe tener, y de hecho tiene, resonancias prácticas. Resonancias de índole muy diversa. Debe desdramatizar la misma realidad de la misión. Ya no puede existir la urgencia casi morbosa que se dio en el pasado. Urgencia que convertía la misión en una labor precipitada y heroica. Con una preparación mínima era suficiente, buscando más el número que la calidad. Es necesario matizar más el valor o la necesidad de la misión cristiana. Hay que rehuir aquí de cualquier tono absolutista. Si la revelación y la salvación de Dios tienen en la persona y la obra de Jesucristo su peculiaridad y universalidad únicas, los caminos a recorrer para hacerla efectiva son variados. La persona y la obra de Jesucristo desbordan el marco eclesial. Si Jesucristo ejerce una capitalidad eclesial, también tiene una capitalidad cósmica. Esta última hace que su actuación salvífica tenga dimensiones cósmicas y alcance, en base a ello, a las demás religiones.

Las fórmulas religiosas sufren también el impacto de la nueva realidad. Por ser Dios lo que es, es decir el inefable y el ininteligible, toda expresión relativa a El padece limitaciones, al tiempo que tiene características peculiares. Ello hace que la misión cristiana evite el inconveniente de creer que sus expresiones sobre Dios y todo lo que a El se refiere son las únicas válidas o, tal vez, las mejores. En algunos aspectos concretos otras religiones habrán formulado mejor la realidad divina. Y ello hay que reconocerlo en fidelidad a la verdad.

Finalmente, hay que tener presente que la misión cristiana debe cambiar su estilo tradicional. No se pueden seguir los caminos de antaño. Hay que renunciar a cualquier atisbo de conquista y entrar por el camino del diálogo.

El diálogo es el instrumento único de la misión moderna. «El Sínodo de los obispos de 1971 insistió en que la promoción de la justicia y la participación en la transformación del mundo son "una dimensión comunitaria" de la misión evangelizadora de la iglesia. Se puede y se debería decir lo mismo del diálogo interreligioso. Más que de partes distintas, se trataría de elementos o dimensiones diversas, o mejor aún, de formas, modalidades o expresiones diferentes de la misión, que es una "realidad unitaria, pero compleja y articulada". Las formas concretas que revista en la práctica la misión evangelizadora dependerá mucho de las circunstancias de tiempo y lugar y del contexto humano -social, económico, político y religioso- en el que se realice. En el contexto de una rica variedad de tradiciones religiosas que aún hoy siguen siendo fuente de inspiración y de valores para millones de fieles, el diálogo interreligioso tendrá que ser naturalmente una forma privilegiada de evangelización. Pueden darse circunstancias en las que, al menos temporalmente, el diálogo sea el único camino abierto para la misión» ${ }^{31}$.

31. DI JPI JIS. I... Jesucristo al encuentro de las religiones. Ed. Paul. Madrid, 1991, 318. 
Aceptado el hecho de la necesidad de la misión para la Iglesia y dibujado el camino a seguir, que no es otro que el camino del diálogo, resta aún retratar algunos detalles que hagan viable la andadura del camino del diálogo. Es absolutamente necesario ponerse en pie de igualdad. Ningún interlocutor del diálogo puede dar la impresión de que lo que dice está por encima, es más verdadero, de lo que dice su otra parte. Es indispensable conocer lo que el otro cree y lo que el otro vive. $\mathrm{Y}$ hay que evitar siempre la descalificación de lo que el otro dice.

El diálogo verdadero no puede caer en las componendas. Se trataría de un eclecticismo mal entendido. $Y$, por lo tanto, incapacitado de entrada para poder dar frutos auténticos. «La integridad de la fe impide, por el mismo motivo, toda componenda o reducción. El diálogo auténtico no puede aceptar los compromisos. No admite el sincretismo que, buscando un terreno común, trata de superar las oposiciones y contradicciones entre las experiencias religiosas de las distintas tradiciones; ni el eclecticismo que, buscando un denominador común entre las distintas tradiciones, escoge de entre los elementos dispersos para combinarlos después en una amalgama informe e incoherente. Para ser auténtico el diálogo no puede ir buscando lo fácil, que, por otra parte, sería ilusorio; sin querer disimular las posibles contradicciones entre las distintas experiencias religiosas, debe asumirlas con paciencia allí donde aparezcan.

Las diferencias o las posibles contradicciones no pueden esconderse ni disimularse; sino que deben ser respetadas mutuamente por los interlocutores del diálogo y asumidas de manera responsable. En efecto, la sinceridad en el diálogo exige que tanto una parte como la otra se comprometa en él en la integridad de su propia fe. Disimular las diferencias y las posibles contradicciones equivaldría a falsearlo y el diálogo mismo dejaría de tener sentido. Pues el diálogo busca la comprensión en la diferencia, la estima sincera de convicciones distintas de las convicciones personales; de este modo consigue que los interlocutores se cuestionen sobre las implicaciones para su propia fe de las convicciones personales de los otros» ${ }^{32}$.

Como se ve, las exigencias de un diálogo auténtico son grandes. Hasta se produce la sensación de que son prácticamente inalcanzables. Por lo que puede sobrevenir la tentación del desaliento y del abandono. Con lo que se cerrarían todos los caminos. La solución no puede ir por ahí. La solución tiene que marchar por el único camino que puede hacerlo: seguir empeñados, como creyentes en Cristo, en «anunciar a los gentiles (palabra con un sentido universal), la inescrutable riqueza de Cristo y esclarecer cómo se ha

32. DUPUIS. J., O. CIT. 324. 
dispensado el Misterio escondido desde siglos en Dios, Creador de todas las cosas, para que la multiforme sabiduría de Dios sea ahora manifestada a los Principados y a las Potestades en los cielos, mediante la iglesia, conforme al previo designio eterno que realizó en Cristo Jesús, Señor nuestro, quien, mediante la fe en él, nos da valor para llegarnos confiadamente a Dios. Por lo cual os ruego que no os desanimáis a causa de las tribulaciones que por vosotros padezco, pues ellas son vuestra gloria (Ef 3,8-13). Quien habla aquí es el apóstol Pablo, insigne modelo de propagador del evangelio. Su figura y su trabajo pueden servir de modelo y orientar siempre la labor apostólica de la iglesia, que, si tiene que cambiar de tono y, en ocasiones, de contenido, no debe perder nunca su conciencia misionera.

A la luz del diálogo los cristianos descubriremos que mucho de lo que queremos presentar como evangelio de Jesucristo no lo es. Se trata de formulaciones acontecidas en el marco de un tiempo y de una cultura determinados. Por lo que no quedará otro camino que prescindir de ellas. Y seguramente también descubriremos que «las semillas del Verbo» se encuentran en el fondo del terreno de otras religiones y han dado y siguen dando verdaderos frutos de salvación. Lo que hace que el campo común sea frecuentemente mucho más amplio de lo que a primera vista pueda aparecer. Ello hará posible que, huyendo siempre de los triunfalismos amenazantes, el encuentro dialogal termine en abundante cosecha de bien. Lo demás, es decir, todo lo que mira a la respuesta concreta personal queda en manos del único que tiene el secreto de los corazones humanos. En última instancia, el Espíritu de Dios es el que tiene que llevar el protagonismo de toda obra que, a la larga, no debe quedar en aceptar un nuevo credo religioso, sino en transformar la vida de una persona. «Esta es la confianza que tenemos delante de Dios. No que por nosotros mismos seamos capaces de atribuirnos cosa alguna, como propia nuestra, sino que nuestra capacidad viene de Dios, el cual nos capacitó para ser ministros de una nueva Alianza, no de la letra, sino del Espíritu. Pues la letra mata, más el Espíritu vivifica» (2 Cor 3,4-6).

Termino este apartado con una hermosa cita de Roger Garaudy. Un personaje que, dada su categoría mental, hace de la cita todo un símbolo. «Sólo hay diálogo verdadero, si, de entrada, cada uno admite que tiene algo que aprender del otro y que, por tanto, está dispuesto a cuestionar algunas de sus certezas. Por eso, el que se compromete a este auténtico diálogo aparece, a veces, como un disidente en potencia ante los ojos de su propia comunidad.

Este diálogo de la fe sólo es posible entre hombres y mujeres para quienes su propia fe no pertenece al ámbito de las respuestas, sino de las preguntas. 
Este diálogo sólo es posible, si cada uno es consciente de que, si Dios es trascendente, es decir, que está muy por encima de nuestras categorías, ideas y palabras, ningún hombre, ni ninguna comunidad puede pretender encerrarle en sus definiciones, en sus ritos o en sus dogmas. Tal "suficiencia" es lo contrario de la "trascendencia".

Esta superación de todas las "ideas" y de todas las "imágenes" que los pueblos se pueden hacer de Dios, se manifiesta en que en todas las religiones reveladas, Dios habla a los hombres en parábolas, utilizando experiencias humanas, para sugerir lo que trasciende toda experiencia y todo concepto. Además, la fe de los que han vivido más en profundidad la presencia divina reconoce que sólo se puede decir lo que Dios no es en una especie de teología negativa. Los grandes místicos de todas las religiones sólo hablan de Dios en metáforas y, en ningún caso, pretenden poder aprehenderle. A lo máximo que aspiran es a intentar acercarse a $\mathrm{El}$ a través del lenguaje poético, que, al contrario del conceptual, no pretende encasillar la realidad en una definición, ni explicar su contenido. Ibn Arabí y san Juan de la Cruz, Rabi’a de Bassorah y santa Teresa de Avila intentaron traducir, a través de poemas y de símbolos, una experiencia que no se puede plasmar en conceptos.

Esta conciencia humilde de lo que le falta y siempre le faltará a nuestra fe para alcanzar lo divino, es la primera condición para poder establecer un diálogo de fe» ${ }^{33 b}$.

Hermoso mensaje que sirve de broche de oro a un tema apasionante y complicado como es el que se acaba de ofrecer.

\section{3.- VENCER LA TENTACION DE VUELTA AL PASADO.}

Es una tentación muy humana y, sobre todo, es una tentación muy propia de grupos religiosos. El hombre busca seguridad o seguridades. No quiere correr riesgos. Y, para ello, lo mejor es refugiarse en el pasado. Cuando se habla de vencer la tentación de vuelta al pasado no se quiere defender una postura que signifique romper a lo bruto con el pasado. Tan sólo se quiere llamar la atención sobre uno de los peligros más frecuentes en la vida del hombre y, en particular, en la vida del creyente. Es el peligro de la absolutización del pasado, de forma que se mire con recelo todo lo que pueda conllevar cambio tanto de ideas como de praxis.

La tendencia involucionista, que tal actitud conlleva, amenaza de forma especial a las instituciones religiosas, sobre todo cuando éstas han estado

33b. GARAUDY. R. ¿Tenemos necesidad de Dios? PPC; Madrid 1993, p.149:150. 
marcadas por un peso dogmático y jurídico. Tal es el caso del cristianismo. Y más en concreto, del catolicismo. ¿En base a qué?. Muchas son las respuestas que pueden darse a la pregunta. Prefiero fijarme en tres:

a.- Los escritos inspirados.

b.- La acuñación dogmático-práctica que de ellos se ha hecho.

c.- El magisterio eclesiástico

\section{a.- Los escritos inspirados}

El cristianismo se apoya en unos escritos a los que concede la categoría de libros inspirados y a los que mira como norma de su fe y de su actuar. Son libros escritos hace muchos años. No venidos del cielo, como durante tanto tiempo se creyó. Con influencias de culturas diversas y de formas de pensamiento religioso en ocasiones extrañas. Ello hace que, en muchos de sus mensajes, se encuentren muy alejados de nuestra cultura, tanto por su contenido, como por su estilo.

Su carácter de libros inspirados, expresión muy general y muy poco precisada, hace que se les conceda un matiz de intocables. Para lo que se ha acuñado la expresión palabra de Dios, expresión a todas luces exagerada. Ello hace que exista en el cristianismo una tendencia natural a mirar al pasado por la necesidad de mirarse en el espejo de tales libros. A lo que hay que añadir algunos aspectos concretos del catolicismo. El catolicismo ha crecido en un clima fuertemente dominado por una cultura romana. Que es lo mismo que decir, por una cultura construida alrededor del derecho. De ahí que tenga una gran dosis de carga jurídica. Lo jurídico suele estar en el polo opuesto de la vida. Es más estático que dinámico. Mira más al pasado y siente cierta repugnancia por lo nuevo.

La Biblia no deja de ser un libro con su carga humana. Está también sometida al vaivén de los tiempos y encuentra en la historia su mejor intérprete. Es decir, lo que la humanidad vive en un momento determinado es la mejor clave para interrogar a la Biblia y encontrar en ella indicadores que puedan ayudar al hombre a ser un ser futurizo. No un ser petrificado.

\section{b.- La acuñación dogmático-práctica que de ellos se ha hecho.}

Los libros, llamados inspirados, han sido el motivo de una acuñación dogmático-práctica ingente. A su embrujo o por su causa se ha construido una literatura tanto teórica como práctica de proporciones gigantescas. Padres de la Iglesia, doctores, teólogos, escritores de diverso signo han intentado construir un corpus doctrinae, que, de una forma o de otra, ha querido ser reflejo de lo dicho en las. Escrituras. El peso de muchos autores ha sido 
tal que sus enseñanzas se aceptaron y se siguen aceptando como una herencia intocable. $\mathrm{Y}$, en algunos casos, sin el ejercicio de un discernimiento adecuado. Lo dijo el Santo tal o cual, el teólogo tal o cual y ya es suficiente. Ello ha producido, además de tendencias abusivas de mirar siempre al pasado, un recelo cuasi-natural sobre todo lo que pueda tener estampa de nuevo. El cambio ha caído siempre mal en ambientes crudamente dogmáticos como es el catolicismo. Machaconamente se repiten las fórmulas y los conceptos, sin pararse a pensar si tienen o no ya sentido. La cantidad de temas, que padecen este mal, es tan grande, que apenas hay espacio para recoger algún tema. Procuraré que sea importante.

Fórmulas, por otra parte, que con etiqueta cristiana, tienen muy poco o nada de cristianas. ¿No es esto lo que sucede con un tema tan decisivo para el creyente cristiano como es el de la espiritualidad?. ¿Y no sucede lo mismo también en un tema tan humano como es el de la sexualidad?. Ni la espiritualidad, ofrecida por el cristianismo, ni la doctrina acerca de sexualidad, presentadas con tarjeta cristiana, son llana y simplemente cristianas. La afirmación es dura. Pero es verdadera. Y, aunque duela, hay que reconocerla.

Es vano, y conlleva la conducta del avestruz, querer ignorar hechos tan evidentes como los reseñados. No es correcto seguir invocando autoridades del pasado, para mantener doctrinas que las investigaciones de nuestro tiempo están dejando en ridículo. Seguir esta consigna es lo mismo que perder el tren de la historia. O, lo que es lo mismo, es vivir a des-tiempo. Si la iglesia y quienes la forman quieren ser una realidad viva y operante, no queda otra alternativa que despojarse del vestido viejo, trasnochado, y vestirse del nuevo, del actual. Ya se sabe que ello lleva un despojo. Y el despojo es doloroso. Pero es el tributo que hay que pagar, si se quiere vivir del Espíritu y salir del recinto amurallado de un pasado, que ya no conecta con el presente y se despreocupa del futuro.

\section{c.- El magisterio eclesiástico.}

Es, de hecho, una realidad eclesial. Y una realidad eclesial que está marcada por unas características muy peculiares en nuestro tiempo. De forma machacona las instancias superiores de la iglesia hablan del tema. Y formulan la necesidad de obedecer ¿ciegamente? a dicho magisterio. El hecho o, mejor, las circunstancias que lo rodean, no dejan de llamar la atención. Uno tiene la impresión de que en la iglesia católica no se puede alcanzar la mayoría de edad. Es decir, la capacidad de pensar por sí mismo y de tomar decisiones responsables por sí mismo. En la raíz de esta impresión se encuentra el ejercicio de un magisterio a todas luces exagerado. 
El magisterio eclesiástico es, sin lugar a dudas, una rémora en la tarea de vencer la tentación de la vuelta al pasado. Tiene un apego cuasi-sacral al pasado. Una y otra vez repite respuestas de antaño a problemas de hoy, sin tomar nota que los problemas, por más que tengan un denominador común, nunca tienen la misma fisonomía. Aplicar soluciones del pasado a problemas del presente es un desacierto. Y esto es lo que está sucediendo en muchos campos del magisterio eclesiástico.

El excesivo apego al pasado es, con toda seguridad, el responsable de esos aires restauracionistas que soplan en la iglesia de hoy. Ejemplos sobresalientes son El Catecismo de la Iglesia Católica y la carta-encíclica de Juan Pablo II Veritatis splendor. En estos documentos se respira un ambiente cultural propiamente escolástico. Terminología y formas de enfocar y solucionar problemas tienen una impronta marcadamente neo-escolástica. Nos encontramos de nuevo ante una moral objetivista. Y se abandona el camino legítimo de una moral de cuño personalista.

Buena muestra de este estilo viejo, revivido ahora por el magisterio eclesial, son unas largas palabras de Pedro Miguel Lamet. «Cuando vinieron los aires nuevos del posconcilio, algunos cristianos respiramos. Los moralistas pusieron el acento en el personalismo. La decisión moral, decían, brota del núcleo autónomo de la persona. Unicamente tiene sentido una decisión ética, cuando es responsable, es decir, cuando es una respuesta del yo ante las exigencias de su propia realización. En una palabra, ya no te podías condenar así, como así por un pecado mortal. (Hace aquí referencia a la forma tradicional de hablar del tema: un pecado mortal bastaba para ir al infierno). Lo que importaba era el estilo global de vida, no unos actos concretos. El discernimiento ético se instalaba entonces preferentemente en la opción fundamental de lo íntimo del ser humano, desde donde se orienta todo el dinamismo de la persona. No son las leyes exteriores de la iglesia las que imponen la moral.

La verdad es que la semana pasada, por si me quedara alguna duda de que hemos retomado el legalismo y el objetivismo moral, Elías Yanes me las quitó. El trato que dio el arzobispo en sus artículos y declaraciones a los homosexuales me devuelve a los oscurantistas tiempos de mi infancia. Si alguno nace con tendencias homosexuales que se fastidie: está condenado de por vida a vivir en castidad perfecta, convertirse en un fraile o en una monja a la fuerza. Sus actos de por sí son intrínsecamente malos, van contra la ley natural. Y lo que la conciencia moral de ese ser humano decida importa un bledo. Detrás, uno no puede dejar de ver el nuevo Catecismo y la encíclica Veritatis splendor, que, como acaba de defender Marciano Vidal, son dos textos restauracionistas que nos retrotraen a los planteamientos de la vieja 
escolástica. "El objetivismo moral se traduce en una moral controlada por el Magisterio eclesiástico", escribe, donde la creatividad de los teólogos queda muy mermada, la visión de los laicos no se hace presente, y se regresa a la fixista "moral de actos"» 34 .

La cita ha sido larga. Ha merecido la pena. Su precisión y valentía hacen de ella una cita modélica para el tema. Efectivamente, nos encontramos hoy en nuestra iglesia católica con un estilo de magisterio que da la espalda al presente y al futuro y mira, no ya con nostalgia, sino con crudo realismo al pasado, empeñado en revivir modelos culturales que poco o nada dicen al hombre de nuestro tiempo. A todo esto hay que añadir la tendencia innata de los agentes del magisterio a acudir a voluntades divinas o crísticas, a la hora de dar respuesta a temas de actualidad. Es un recurso fácil. Pero es un recurso que la piqueta del tiempo desmorona, como si se tratara de un castillo de naipes. Es imposible marginar en el momento la declaración solemne de Juan Pablo II sobre el tema del mal llamado acceso de la mujer al sacerdocio. La declaración, hecha en un tono inusitado, no deja de producir sorpresas. Y está tocada de la tendencia que antes apuntaba. Se quiere ver en el tema una supuesta voluntad de Cristo, que confió, según se dice, a solo varones el ministerio sacerdotal o, sin más, el sacerdocio. Es sorprendente decir esto en los tiempos en que estamos y con los conocimientos históricamente ciertos que se dan al respecto. Pero el dato está ahí. Y vendrá con seguridad a engrosar ese número de declaraciones magisteriales hechas por el Papa u otros estamentos eclesiales y deshechas después por otro Papa o por otros estamentos eclesiales. La historia del magisterio eclesiástico, desde esta perspectiva, no es muy boyante. Al contrario. Es escasamente boyante. Y produce más que respeto y aceptación desinterés y rechazo. El Syllabus, la encíclica de S. Pío X Pascendi, condenando sin más el Modernismo, la encíclica Humani generis de Pío XII, rechazando la Nueva Teología, la encíclica de Pablo VI Humanae vitae, condenando los anticonceptivos, y, entre otras, la encíclica Veritatis splendor, que revive la moral objetivista, son unos buenos ejemplos en el tema que me ocupa. Y manifiestan la tendencia cuasi-innata del magisterio eclesiástico a desconfiar del sentido dinámico de la vida humana y a aplicar soluciones del pasado en contenido y en lenguaje a temas del presente. Si esta tendencia no se supera, la posibilidad y la eficacia de una nueva evangelización serán, desde el punto de vista humano, una insulsa utopía.

34. LAMET. P. M., Los homosexuales y el pecado mortal. La Crónica 16, Lunes 27 de junio de 1994. p. 23. 


\section{4.- SUPERAR LA INCOHERENCIA.}

Es uno de los temas que más me llaman la atención. He reflexionado con muchísima frecuencia sobre él. Y siempre he llegado a la misma consecuencia: el magisterio eclesial es incoherente en bastantes de sus afirmaciones. Habla, por ejemplo, de que los cristianos tienen que ser personas maduras, para lo que es indispensable poder tomar decisiones personales, y luego te impone una serie de obligaciones, normalmente nacidas en supuestas voluntades divinas, que ahogan y asfixian la iniciativa personal. Un caso modélico en el tema lo tenemos en lo que mira a la natalidad. Resulta que la enseñanza de la Iglesia está llamando a que se dé en el campo matrimonial una paternidad y una maternidad responsables, lo que me parece estupendo, pero inmediatamente vienen las cortapisas. Tal paternidad o maternidad responsables se ven coaccionadas por una serie de cortapisas que, con toda seguridad, uno concluye que todo ese bonito mensaje se queda en meras palabras. Ya no son los padres responsables los que poseen el derecho de decidir sobre el número de hijos a tener responsablemente y los modos de conseguirlo, si no es la autoridad eclesiástica la que marca el camino. La incoherencia es dramáticamente gorda. Y así no se puede llegar a la gente y ofrecerle con una pequeña garantía humana un mensaje que además se quiere presentar como mensaje liberador. El cristianismo, acuñado de esta forma, no deja de ser un instrumento de dominio en manos de unos pocos. Un instrumento, por lo demás, tanto más repugnante, cuanto se quiere ofrecer como cosa querida por Dios.

El tema, que me ocupa, ha tenido una exposición aguda y fuerte en un artículo aparecido en Selecciones de Teología 116 (1990) pp. 302-308, cuyo título es de suyo sorprendente: Adhesión a los derechos humanos; desconocimiento de los «derechos cristianos»: la incoherencia romana. Su autor es Bernard Quelqueyeu. Como resumen del contenido del artículo se pueden considerar estas palabras: «El contraste que se da entre el compromiso actual de la iglesia romana por el respeto y la promoción de las libertades y derechos del hombre en los campos civiles, sociales y políticos, y la capacidad de las autoridades romanas para respetar y promover la libertad cristiana dentro de la iglesia, es algo que produce asombro» ${ }^{35}$.

Tras esta síntesis, que va confirmando con datos históricos, datos, por lo demás, que cualquiera puede detectar, si tiene la paciencia de estudiar la historia, el autor organiza su reflexión alrededor de una serie de puntos. Ellos

35. QUELQUEJEU. B., Adhesión a los derechos humanos: desconocimiento de los «derechos cristianos»: La incoherencia romana, en Selecciones de Teología 116 (1990) p. 302. 
son:

1.- El derecho de los fieles en el nuevo Código de Derecho Canónico.

2.- El procedimiento de la Congregación para la doctrina de la fe.

3.- Procedimientos y criterios para el nombramiento de los obispos.

4.- Elaboración de la doctrina moral católica.

5.- Lugar de las mujeres en la iglesia ${ }^{36}$.

Como se puede apreciar todos los puntos son de enorme interés y tienen una incidencia muy directa en la sensibilidad humana moderna. Ante la imposibilidad de detenerme en cada uno de los puntos, tomo la opción de fijarme en el que habla de «la elaboración de la doctrina moral católica». Ni que decir tiene que se hace con la mayor delicadeza posible y con el máximo respeto. Se interpretaría erróneamente lo que se va decir, si se pensara que hay en ello algún mínimo atisbo de aversión o antipatía. Lo que sí hay es el derecho a una crítica, al que nunca se debe renunciar, si se quiere vivir en madurez y en responsabilidad la condición de creyente en Cristo.

«Un cuarto ejemplo, dice Bernard Quelqueyeu, de la incapacidad de la iglesia para extraer, en su práctica interna, las consecuencias de su reconocimiento de los derechos humanos y libertades modernas lo proporciona la elaboración de la doctrina moral.

Los ejemplos son numerosos y recientes. Hay que recordar el largo proceso de reflexión llevado a cabo en tiempos de Juan XXIII y Pablo VI para llegar al dramático resultado de la Humanae vitae. Pone en escena a todos los actores eclesiales: los laicos, los diversos expertos y especialistas, los teólogos moralistas y pastorales, los obispos, las comisiones pontificias, los cardenales, el concilio, el papa. Pone en evidencia la sistemática desposesión del derecho a dar su opinión de abajo arriba, cuando se trata de doctrina moral, de los fieles, de los expertos, después de los obispos y por fin de los cardenales. La lógica de esta desposesión es implacable.

Más reciente, basta con evocar la historia de la Donum vitae de 1987 sobre el respeto a la vida humana que nace y la dignidad de la procreación. Aunque se habla de una amplia consulta, se sabe que los expertos solicitados fueron cuidadosamente seleccionados; que no se tuvo en cuenta la opinión de numerosos obispos, ni la propuesta de consulta emanada del Presidente de la Federación Internacional de las Universidades Católicas, a pesar de estar éstas especialmente afectadas debido a los hospitales católicos.

La incapacidad de la iglesia simplemente para entender la experiencia moral y cristiana de los fieles desemboca en la negación del derecho de los fieles a buscar y adoptar, en la libertad responsable de su conciencia, com-

36. Ib. 305-306. 
portamientos morales en materia de vida individual y colectiva. El resultado es el dramático alejamiento entre las posiciones oficiales en materia de doctrina y el estado real de las conciencias vivas y de las prácticas de millones de cristianos, alejamiento que ha adquirido en algunos casos las dramáticas dimensiones de un abismo» ${ }^{37}$.

Seguramente que los párrafos citados producen extrañeza y, en ocasiones, hasta escándalo. ¿Cómo es posible que instituciones con vitola tan alta de santidad como es la iglesia católica pueda llegar a extremos como los que refleja Bernard Quelqueyeu?. Sí, sí, la cosa tiene todos los visos de llamativa. Produce una sensación de sorpresa desagradable. Y uno pudiera caer en la tentación de calificar lo recordado como una especie de rabieta e, incluso, de algo totalmente infundado. Sería una reacción irracional. Los datos históricos pasados y presentes confirman lo apuntado por el autor. No hay coherencia en muchas ocasiones en lo que la iglesia afirma en niveles diversos. $\mathrm{La}$ metodología que usa para hacer frente a posibles desviaciones de teólogos es una metodología impropia de situaciones históricas como las que vive el mundo moderno. Todos los Derechos reconocen a los ciudadanos derechos que la iglesia pasa por alto. $\mathrm{Y}$ todo esto lo hace en nombre de un Dios, del que se considera representante directo, y del que ofrece, sin más, una imagen antipática y fea. Lo que el autor afirma en los párrafos anteriores es una pequeña muestra nada más de un estilo en el ejercicio del magisterio y de la autoridad que se halla a años luz de lo que acontece en el mundo.

Una vez expuestos los distintos puntos en lo que aparecen las incoherencias de la enseñanza romana, el autor aborda el tema sugestivo de explicar el fenómeno. Las cosas no suceden sin más ni más. «Una contradicción tan manifiesta, dice, deriva sin duda de condicionamientos profundos, de causas que actúan de forma muy poderosa y en gran parte sin que lo sepan los mismos interesados, de una inconsciencia institucional inveterada desde hace siglos, y que sigue produciendo sus efectos aún cuando la conciencia en sí, al menos de modo superficial, se ha modificado un poco» ${ }^{38}$.

Los temas de fondo, que originan tal cantidad de incoherencias, son éstos:

1.- La iglesia guardiana de una cristiandad amenazada.

2.- Adhesión a los derechos del hombre, pero ¿a cuáles?.

3.- Obsesión de la salvaguarda institucional y de poder.

4.- Sexualidad y poder.

Tal vez hay en estos enunciados algunos que nos resultan extraños. De

37. Ib. 305 .

38. Ib. 306. 
los que no alcanzamos a descubrir su contenido. En razón de este dato, voy a recoger aquí lo que el autor citado dice acerca del primero y del cuarto. «La actitud contradictoria de la autoridades romanas es, según los historiadores, el resultado de una historia plurisecular.

El mensaje de Jesús y de la iglesia primitiva había ayudado poderosamente a los hombres a tomar conciencia de la verdadera dignidad de la persona. Durante los primeros siglos no dejó de reivindicar lo que hoy llamamos los derechos de la conciencia en contra de las pretensiones del poder imperial. A partir de 313 la iglesia se encuentra investida del liderazgo social y cultural de Occidente... y las consecuencias de ello serán inmensas. Se asiste al despliegue de los apologistas de la violencia de Estado al servicio de la ortodoxia doctrinal... Del anuncio de la verdad, que hace libre se pasa a la defensa de la cristiandad contra todo lo que la amenaza; esto supone adoptar, de manera muy profunda, pronto legitimada teóricamente, la ideología del orden establecido. Desde esta perspectiva, la reivindicación de los derechos del individuo no podía dejar de aparecer como subversiva. Pío IX en 1864 condena sin apelación la libertad de elegir la propia religión. El lenguaje del anatema se imponía en una iglesia que dedicaba gran parte de sus fuerzas a la defensa de una cristiandad amenazada.

La profundidad de esta herencia hace que la iglesia sea capaz de denunciar ad extra las patologías del poder social y político, pero no de modificar la conciencia que la iglesia tiene de sí misma para que aprenda a ver enfermedades de la institución eclesial». ${ }^{39}$.

Sobre el cuarto punto, sexualidad y poder el autor ofrece unos datos muy elocuentes. «Cuando se supo en el concilio Vaticano II que por voluntad del Papa se había retirado de la competencia del Concilio el tema de la regulación de la natalidad, Máximos IV exclamó: "Ciertas posiciones oficiales... son tributarias de concepciones superadas y, quizás también, de una psicosis de celibatarios ajenos a este sector de la vida". Es digno de interés el hecho de que las tres cuestiones sustraídas -regulación de la natalidad, celibato de los sacerdotes, ordenación de mujeres- afecten a la sexualidad. El proceso de la Humanae vitae está en la misma línea. ¿Qué tema produce tal bloqueo de las instituciones, tal psicosis colectiva? ¿Un tema dogmático? No. La licitud de un método anticonceptivo. Sobre un asunto de control normativo de un comportamiento sexual, la autoridad romana compromete todos sus recursos; este hecho da mucho que pensar. Hay que llegar a creer que, para ella, se trata, en definitiva, de su poder mismo. Uno empieza a sospechar con Máximos IV, que la situación exclusivamente masculina y celiba-

39. Ib. 306. 
taria del clero católico podría pesar mucho en este asunto. Y que el problema crucial invocado cada vez - el carácter irreformable de la doctrina- deja entrever que el deseo de omnisciencia, de omnipotencia y de infalibilidad, que obsesiona a tal aparato, se debería a lazos ocultos, pero rigurosos, que unen sexualidad y poder» ${ }^{40}$.

Creo que lo recordado es más que suficiente para mostrar incluso demostrar, que la iglesia, en sus instituciones superiores, presenta bastantes lagunas en el campo de la coherencia. Ello supone un grave, gravísimo inconveniente para la nueva evangelización. Si no se corrige, todo quedará en luces de Bengala. Se producirá un gran resplandor, pero será tan pasajero que luego no quedará más que una nueva noche oscura.

La superación de la incoherencia es una necesidad para cualquier mensaje o contenido ideológico. En el caso del mensaje cristiano tal necesidad se hace más perentoria, debido a sus características tan peculiares. Se afirma de él que es un mensaje venido del cielo. El Dios-verdad está por medio. También se dice que es un mensaje con aspiraciones universales. Lo cual acentúa a más la necesidad de coherencia. Ello exige que se borre del mensaje cristiano todo lo que pueda oler a humo de esclavitud. La iglesia tiene que ser la institución que más favorezca la libertad. Si, por una u otra causa, no lo hace, entonces compromete seriamente el mensaje que tiene que trasmitir.

Por ser labor eclesial es labor de todos los creyentes. Nada se adelanta con lamentaciones inútiles y menos con posturas inhibicionistas. No es uno mejor creyente, cuando dice amén a todo lo que viene de arriba, es decir, de las instituciones superiores eclesiales, sin aceptar el reto de hacer una crítica constructiva al respecto. Siguiendo esta línea, me he permitido criticar doctrinas, actuaciones dentro del tejido de la iglesia, que, según todos los indicadores, no responden a la verdad y a la coherencia evangélicas. Esa fue la línea seguida por Máximos IV, el gran Patriarca de los Maronitas y una de las grandes figuras del concilio Vaticano II, según queda reseñado en los párrafos anteriores.

\section{5.- DIALOGAR CON EL MUNDO Y NO LUCHAR CONTRA EL MUNDO.}

El mundo, del que hablo aquí, es el mundo de la cultura. Se trataría en este tema de un diálogo entre fe y cultura, cultura y fe, superando el enfrentamiento entre ambas. Enfrentamiento que no puede traer más que resultados negativos.

40. Ib. $307-308$ 
La fe y la cultura son dos fuentes de información, que, si tienen campos muy definidos y diversificados, también se entrecruzan mutuamente. Ni la fe puede hacer oídos sordos de lo que la cultura investiga, ni la cultura puede marginar temas de la fe. Y ello, porque una y otra están al servicio del hombre, en el que encuentran su razón de ser. Más aún: frecuentemente, por no decir siempre, ambas tienen como punto de referencia al hombre. $\mathrm{O}$, si se quiere dar una imagen sugestiva, ambas son como dos ríos que terminan, después de un cierto recorrido, uniendo sus caudales. En base, pues, a que una y otra están al servicio del hombre, se impone la necesidad de un diálogo entre ambas.

La relación entre iglesia, espacio en el que la fe vive y se desarrolla, y el mundo, lugar en donde la ciencia encuentra su campo de cultivo, no ha sido, en general, muy boyante. El problema alcanza un nivel muy alto en los tiempos modernos y logra su máxima cota a finales del siglo XVIII y durante todo el siglo XIX y gran parte del XX. La revolución francesa, acontecida a finales del siglo XVIII, marca el inicio de una lucha abierta y despiadada entre la iglesia y el mundo. Históricamente, la revolución francesa constituye el final del «antiguo régimen». Es decir, del régimen feudal, en el que la sociedad estaba configurada por dos estamentos bien definidos: uno, reducido, el de los dominadores; otro, amplio, el de los dominados o explotados. La iglesia se estanca en su constitución feudal y se opone frontalmente a las nuevas ideas. La alta temperatura de este clima de oposición está reflejada en esta frase del Syllabus. «EI Romano Pontífice puede y debe reconciliarse y transigir con el progreso, con el liberalismo y con la investigación moderna» ${ }^{41}$. Es bien claro que esta proposición se condena. Por lo que la contraria es la verdadera. Y suena así: «El Romano Pontífice no puede ni debe reconciliarse y transigir con el progreso, con el liberalismo y con la civilización moderna».

¡Asombroso! Pero ahí está el hecho y lo que tras él se esconde. Porque si el Romano Pontífice debe estar divorciado, irreconciliado con el progreso, el liberalismo y la civilización moderna, dada la relevancia de su persona en la iglesia y lo que simboliza, el contenido de la proposición afecta a toda la iglesia. La iglesia tampoco debe reconciliarse con el progreso, el liberalismo y la civilización moderna. En una tal texitura no puede haber más que ruptura o enfrentamiento entre iglesia y mundo cultural. Entre lo que acontece en el mundo y lo que la iglesia alimenta en su seno. No estamos ante dos realidades hasta cierto punto diversas, sino ante dos realidades enfrentadas y distanciadas. Enfrentamiento y distanciamiento que irán creciendo con el 
correr del tiempo. Mientras el mundo avanza, y avanza por medio de una cultura cada vez más caudalosa, la iglesia se esclerotiza bajo la coraza de una dogmática repetitiva y alejada de la vida. Lo más grave del problema está en que todo este conjunto de cosas, mezcla de irracionalidad y contradicciones, se construye sobre las ruinas de una víctima, que siempre paga las consecuencias negativas: el hombre creyente. Sobre todo, el creyente perspicaz, que tiene inquietud, que se pregunta por lo que cree, que quiere tener razones de su esperanza, que no se contenta con una fe incorrectamente llamada ciega. El tal creyente no puede marginar un sentimiento de vergüenza, cuando se siente miembro de una institución que oficialmente se ha declarado irreconciliada con el progreso, el liberalismo y la civilización moderna. Y que, fruto de esa actitud de base, sigue tratando problemas nuevos con fórmulas viejas. Como si la ciencia se hubiera estancado en tiempos de los Padres de la iglesia, de los teólogos del siglo XIII y las últimas soluciones las hubieran dado el concilio de Trento o el Vaticano I.

La consigna, marcada por el Syllabus, permaneció casi virgen hasta los umbrales del concilio Vaticano II. Casi toda la literatura católica padeció el síndrome del retrogradismo. La iglesia católica fue calificada de oscurantista y retrógrada. Calificativos que se ganó a pulso. Da grima leer hoy documentos de Papas, cartas pastorales de obispos del siglo XIX y parte del XX, en los que aparece una fobia irracional a todo lo que sonara a liberalismo o marxismo. Las obras de algunos pocos autores, que intentaron romper el muro acordonado de una ortodoxia petrificada, terminaron en ese nefasto catálogo de libros prohibidos, llamado El Indice.

Hasta tanto se llegó en el clima de desconocimiento o enfrentamiento que la iglesia, encerrada cada vez más en los muros impermeables de su realidad, se aisló casi al completo de todo lo que acontecía en el mundo de la cultura. Sobre todo, la iglesia desconfió siempre de cualquier movimiento humano que implicara reconocimiento de libertades o derechos humanos. Se entiende muy bien que, fruto de esa actitud ultraconservadora, la iglesia no reconociera la Declaración de los derechos humanos, hecha por la ONU en 1948, hasta el Pontificado de Juan XXIII. Una repetitiva señal de que la iglesia prefiere modelos de sociedad o esquemas de convivencia claramente autoritarios. Mal que todavía le afecta, a pesar de haber tenido en su seno un concilio tan simpatizante con el mundo moderno como el Vaticano II. Las formas de actuación de las Congregaciones romanas en temas de acusación y judiciales están alejadas de lo que acontece en el mundo. Son, en el fondo, formas que se pasan por alto los derechos fundamentales de la persona. Hay, al respecto, entre otros, un libro del P. Bernard Häring, el moralista más ilustre del siglo $\mathrm{XX}$, que constituye todo un símbolo. Se titula: Mi experien- 
cia con la iglesia. Todo el libro es un testimonio elocuente de las vejaciones que, bajo capa de la necesidad de una ortodoxia a ultranza, se cometen contra las personas. En tales procesos los derechos humanos brillan por su ausencia. El acusado no tiene otra alternativa que plegarse a lo que se le inculpa, aunque ello conlleve claudicar a la propia conciencia, o tirarlo todo por la borda y alejarse de una iglesia oficial, que usa en sus procedimientos estilos des-humanizados y hasta anti-humanos.

He recordado líneas atrás al concilio Vaticano II. Voy a detenerme un tanto en este acontecimiento eclesial, el más grande y significativo del siglo XX. El concilio Vaticano II supuso en su tiempo y, si se siguen sus líneas maestras, supone en nuestro tiempo un cambio de actitud. La magna Asamblea aborda el tema de las relaciones entre iglesia y mundo en la gran Constitución Gaudium et Spes. Se caracteriza este gran documento por el tono de cercanía y acogida $a$ y de la cultura moderna.

El clima de simpatía por la cultura moderna, presente vivamente a lo largo de la Constitución, alcanza su nivel más en los nn. 40-42. Merece la pena recoger aquí, si no todo, sí una parte muy sustanciosa, de lo que el concilio Vaticano II dice sobre el tema. «Todo lo que llevamos dicho sobre la dignidad de la persona humana, sobre la comunidad humana, sobre el sentido profundo de la actividad del hombre, constituye el fundamento de la relación entre iglesia y mundo, y también la base para su mutuo diálogo. Por tanto, en este capítulo, presupuesto todo lo que ya ha dicho el Concilio sobre el misterio de la iglesia, va a ser objeto de consideración la misma iglesia en cuanto que existe en este mundo y vive y actúa con él» ${ }^{42}$.

Tras este párrafo programático, el concilio Vaticano II entra de lleno en el tema. Y comienza por constatar y definir qué es lo que la iglesia puede aportar a cada hombre. «El hombre contemporáneo camina hoy hacia el desarrollo pleno de su personalidad y hacia el descubrimiento y afirmación crecientes de sus derechos. Como a la iglesia se ha confiado la manifestación del misterio de Dios, que es el fin último del hombre, la iglesia descubre con ello al hombre el sentido de la propia existencia, es decir, la verdad más profunda acerca del ser del hombre. Bien sabe la iglesia que sólo Dios, al que ella sirve, responde a las aspiraciones más profundas del corazón humano, el cual nunca se sacia plenamente con solos los elementos terrenos. Sabe también que el hombre, atraído sin cesar por el Espíritu de Dios, nunca jamás será totalmente indiferente ante el problema religioso, como lo prueban no sólo la experiencia de los siglos pasados, sino también múltiples testimonios de nuestra época. La presencia misma de la iglesia le recuerda al hombre

42. CONCILIO VATICANO II. GS. 40a. 
tales problemas; pero es sólo Dios, quien creó al hombre a su imagen y lo redimió del pecado, quien puede dar respuesta cabal a estas preguntas, y ello por medio de la revelación en Cristo, su Hijo, que se hizo hombre. El que sigue a Cristo, hombre perfecto, se perfecciona cada vez más en su propia dignidad de hombre.

Apoyada en esta fe, la iglesia puede rescatar la dignidad humana del incesante cambio de opiniones que, por ejemplo, deprimen excesivamente o exaltan sin moderación alguna el cuerpo humano. No hay ley humana que pueda garantizar la dignidad personal y la libertad del hombre con la seguridad que comunica el Evangelio de Cristo, confiado a la iglesia. El Evangelio anuncia y proclama la libertad de los hijos de Dios, rechaza todas las esclavitudes, que derivan en última instancia del pecado; respeta santamente la dignidad de la conciencia y su libre decisión; advierte sin cesar que todo talento humano debe redundar en servicio de Dios y bien de la humanidad; encomienda, finalmente, a todos a la caridad de todos. Esto corresponde a la ley fundamental de la economía cristiana. Porque, aunque el mismo Dios es Salvador y Creador, e igualmente también Señor de la historia humana y de la historia de la salvación, sin embargo, en esta misma ordenación divina la justa autonomía de lo creado, y sobre todo del hombre, no se suprime, sino más bien se restituye a su propia dignidad y se ve en ella consolidada.

La iglesia, pues, en virtud del Evangelio que se le ha confiado, proclama los derechos del hombre y reconoce y estima en mucho el dinamismo de la época actual, que está promoviendo por todas partes tales derechos. Debe, sin embargo, lograrse que este movimiento quede imbuido del espíritu evangélico y garantizado frente a cualquier apariencia de falsa autonomía. Acecha, en efecto, la tentación de juzgar que nuestros derechos personales solamente son salvados en su plenitud, cuando nos vemos libres de toda norma divina. Por esa vía, la dignidad humana no se salvaría, más bien perecería» ${ }^{43}$.

Tras expresar con un alto tono humanístico que es lo que la iglesia puede ofrecer a una visión digna del hombre, superando así visiones incorrectas del hombre, ya sea por defecto, ya por exceso, el concilio Vaticano II pasa a tratar el tema a un nivel ya de humanidad. ¿Qué puede y debe dar la iglesia a la sociedad humana? «La unión de la familia humana cobra sumo vigor y se completa con la unidad, fundada en Cristo, de la familia constituida por los hijos de Dios.

La misión propia que Cristo confió a la iglesia no es de orden político, económico o social. El fin que le asignó es de orden religioso. Pero precisamente de esta misma misión religiosa derivan tareas, luces y energías que

43. Ib. 41a,b,c y d. 
pueden servir para establecer y consolidar la comunidad humana según la ley divina. Más aún, donde sea necesario, según circunstancias de tiempo y lugar, la misión de la iglesia puede crear, mejor dicho, debe crear, obras al servicio de todos, particularmente de los necesitados, como son, por ejemplo, las obras de misericordia u otras semejantes.

La iglesia reconoce, además, cuanto de bueno se halla en el actual dinamismo social: sobre todo la evolución hacia la unidad, el proceso de una sana socialización civil y económica. La promoción de la unidad concuerda con la misión íntima de la iglesia, ya que ella es «en Cristo como sacramento o señal e instrumento de la unión íntima con Dios y de la unidad de todo el género humano». Enseña así al mundo que la genuina unión social exterior procede de la unión de los espíritus y de los corazones, esto es, de la fe y de la caridad, que constituyen el fundamento indisoluble de su unidad en el Espíritu Santo. Las energías que la iglesia puede comunicar a la actual sociedad humana radican en esa fe y en esa caridad, aplicadas a la vida práctica. No radican en el mero dominio exterior ejercido con medios puramente humanos...

El Concilio aprecia con el mayor respeto cuanto de verdadero, de bueno y de justo se encuentra en las variadísimas instituciones fundadas ya o que incesantemente se fundan en la humanidad. Declara, además, que la iglesia quiere ayudar y fomentar tales instituciones en lo que de ella dependa y pueda conciliarse con su misión propia. Nada desea tanto como desarrollarse libremente en servicio de todos, bajo cualquier régimen político que reconozca los derechos fundamentales de la persona y de la familia y los imperativos del bien común» ${ }^{44}$.

Se entretiene todavía el Concilio en presentar aspectos positivos que la iglesia por medio de su hijos puede aportar a la familia humana. Pero me parece que lo recordado es más que suficiente para tomar buena nota de las disposiciones eclesiales a la hora de colaborar con el mundo en la tarea de alcanzar niveles verdaderamente altos en la visión del hombre y en la forma en que debe orientar sus tareas terrenas. De ahí que toca ahora abordar el segundo aspecto del problema: ver qué es lo que la iglesia reconoce haber recibido del mundo. Con ello se completa el diálogo que ambas entidades deben mantener para mejor servicio del hombre. «La iglesia reconoce los muchos beneficios que ha recibido de la evolución histórica del género humano».

La experiencia del pasado, el progreso científico, los tesoros escondidos en las diversas culturas, permiten conocer más a fondo la naturaleza humana, abren nuevos caminos para la verdad y aprovechan también a la iglesia. 
Esta, desde el comienzo de su historia, aprendió a expresar el mensaje cristiano con los conceptos y en la lengua de cada pueblo, y procuró ilustrarlo además con el saber filosófico. Procedió así a fin de adaptar el Evangelio al nivel del saber popular y a las exigencias de los sabios, en cuanto era posible. Esta adaptación de la predicación de la palabra revelada debe mantenerse como ley de toda evangelización. Porque así en todos los pueblos se hace posible expresar el mensaje cristiano de modo apropiado a cada uno de ellos $\mathrm{y}$, al mismo tiempo, se fomenta un vivo intercambio entre la iglesia y las diversas culturas. Para aumentar este trato, sobre todo en tiempos como los nuestros, en que las cosas cambian tan rápidamente y tanto varían los modos de pensar, la iglesia necesita de modo muy peculiar la ayuda de quienes, por vivir en el mundo, sean o no sean creyentes, conocen a fondo las diversas instituciones y disciplinas y comprenden claramente la razón íntima de todas ellas. Es propio de todo el pueblo de Dios, pero principalmente de los pastores y de los teólogos, auscultar, discernir e interpretar con la ayuda del Espíritu Santo, las múltiples voces de nuestros tiempo y valorarlas a la luz de la palabra divina, a fin de que la verdad revelada pueda ser mejor percibida, mejor entendida y expresada en forma más adecuada.

La iglesia, por disponer de una estructura social y visible, señal de su unidad en Cristo, puede enriquecerse, y de hecho se enriquece, también con la evolución de la vida social, no porque le falte en la constitución que Cristo le dio elemento alguno, sino para conocer con mayor profundidad esta misma constitución, para expresarla de forma más perfecta y para adaptarla con mayor acierto a nuestros tiempos. La iglesia reconoce agradecida que, tanto en el conjunto de su comunidad como en cada uno de sus hijos, recibe ayuda variada de parte de los hombres de toda clase y condición. Porque todo el que promueve la comunidad humana en el orden de la familia, de la vida económico-social, de la vida política, así nacional como internacional, proporciona no pequeña ayuda, según el plan divino, también a la comunidad eclesial, ya que ésta depende asimismo de las realidades eternas. Más aún, la iglesia confiesa que le han sido de mucho provecho y le pueden ser todavía de provecho la oposición y aún la persecución de sus contrarios» ${ }^{45}$.

Han sido largas las citas. Pero creo que están justificadas. Su estilo, su contenido, su tono son de tal calidad que casi es imposible superarlos. El concilio Vaticano II ha expresado bellamente cómo debe ser la relación entre iglesia y mundo. No puede ser otra que la plasmada por un diálogo sincero y abierto. Un diálogo que haga posible la colaboración mutua, con el fin de que una y otro contribuyan lo mejor posible a que el hombre alcance su

45. Ib. $44 a, b$ y c. 
verdadera y legítima estatura humana. El concilio Vaticano II deja bien a las claras cuáles son sus intenciones frente al mundo de la cultura. Ha pasado ya la hora del enfrentamiento o del desconocimiento. Quiere, ante todo, dialogar. Quiere «auscultar, discernir e interpretar» lo que una fórmula afortunada ha llamado signos de los tiempos. Entre los cuales, indiscutiblemente, se encuentra el fabuloso avance científico responsable de muchas rectificaciones en campos diversos. Nuestra visión del hombre ha cambiado en aspectos muy significativos. Tanto a nivel de estructura, como a nivel de relación. El cuerpo y la materia, tan denigrados en antropologías pasadas, han logrado colocarse en su justo punto. Se han superado también visiones del hombre que lo anulaban frente a Dios y que exigían un tutelarismo absurdo por parte de la autoridad eclesiástica. En ello se apoya ese nuevo humanismo, del que habla el Concilio, y en el que la responsabilidad humana ya no se apoya en Dios, sino en el mismo hombre.

Entre los fines, que el Concilio asigna a este diálogo con el mundo, se halla el que «la verdad revelada pueda ser mejor percibida, mejor entendida y expresada de forma más adecuada». Se trata de una bonita y necesaria tarea. Bonita, porque marca un camino dinámico a seguir. Necesaria, porque los contenidos de la revelación han llegado al hombre revestidos de formas culturales y en lenguajes tributarios del tiempo. Muchas de esas formas culturales y mucho de ese lenguaje han dejado de ser significativos para el hombre de nuestro tiempo. Necesitan recibir el aliento vivificador de lo nuevo. $Y$ así poder encontrar acogida en el hombre de nuestro tiempo. Una tarea difícil. Sí. Pero indispensable. Nada se gana con seguir repitiendo mensajes que no entroncan con la forma de ser del hombre moderno.

El concilio Vaticano II ha dejado bien claro cuál es su postura frente al mundo de la cultura. La mira con simpatía. Y quiere mantener un diálogo abierto con ella. Todo ello buscando un servicio más adecuado al hombre, ya que el hombre es la razón o el camino de la iglesia.

Han pasado ya bastantes años desde que aquella magna Asamblea se pronunciara en la forma que acabo de recordar. Podemos preguntarnos ahora: ¿Sigue la iglesia de hoy en sus instancias magisteriales el camino marcado por el concilio Vaticano II? ¿Hay de verdad hoy un diálogo abierto entre iglesia y mundo, mundo e iglesia? Síntomas hay de que ese diálogo se ha enfriado. Aquella bocanada de aire fresco y limpio se está enrareciendo. El magisterio vuelve a hablar un lenguaje objetivista y des-historizado. Los contenidos, por lo demás, están en la calle. Las soluciones ofrecidas por las instancias mundanas y las instancias eclesiásticas se hallan absolutamente alejadas. Un buen ejemplo, se pueden múltiplicar, de este clima de lejanía lo constituye el tema de la sexualidad. Un tema de profundas raíces humanas. 
Un tema englobante. Por lo que, de alguna manera, prolonga su sombra sobre todo o casi todo lo que afecta a una visión correcta del hombre. Por revestir tales características, me voy a permitir detenerme un poco en él. Ya en líneas anteriores recordé algunos pensamientos de Miguel Lamet sobre una parte de este tema. Ahora me voy servir de un artículo aparecido en Selecciones de Teología, $\mathrm{n}^{\circ} 131,1994$. El título del artículo es éste: Sexualidad e institución. Hacia una nueva moral sexual. El título, como se ve, es ya significativo: Hacia una nueva moral sexual. Lo que indica que ya no sirve la antigua moral. Es necesario romper el cerco y marcar nuevos caminos en un tema tan fundamental para el equilibrio de la persona humana.

El artículo de Selecciones de teología está tomado y resumido de la Revista Encrucijada, revista gallega de pensamiento cristiano. Su autor es Carlos Domínguez. Comienza el resumen con estas palabras: «La distancia es cada día mayor entre lo que los fieles piensan, sienten y experimentan sobre la sexualidad y lo que se desprende del discurso eclesiástico, cada día más obsoleto y más distante del objetivo prioritario de orientar la conducta moral del pueblo de Dios. Aumenta el número de creyentes practicantes que, incluso desde posturas conservadoras, prescinden en este tema de las orientaciones morales de la jerarquía, sintiéndose absolutamente libres para conformar su conducta sexual según su propia conciencia.

El problema es grave. Por un lado, se ve afectado el sentido de la eclesialidad y de la comunión del pueblo de Dios: la distancia entre la institución jerárquica y los fieles -por las importantes ramificaciones personales y sociales- puede llegar a convertirse en una distancia generalizada que ya parece mostrar síntomas auténticamente esquizoides. Por otro lado, la misión evangelizadora de la iglesia sufre graves repercusiones: con su discurso sobre la sexualidad la institución eclesiástica se sitúa en una onda cada día más difícil de ser captada por una sensibilidad que ha sufrido, en torno al sexo, transformaciones radicales» ${ }^{46}$.

Las palabras citadas formulan una situación enormemente grave. Es preciso reconocerla. Nada se adelanta con cerrar los ojos a la realidad y, si se quiere, menos, con decir que todo ello acontece porque estamos en una sociedad des-cristianizada o que ha perdido el sentido religioso. Las salidas de este estilo son frecuentes. Mas no resuelven nada. Se nos habla de un distanciamiento entre lo que la jerarquía dice acerca de la sexualidad y lo que los creyentes hacen en su vida. Situación que compromete de hecho la comunión eclesial. Un dato de importancia trascendental y al que no se puede

46. DOMINGUEZ. C., Sexualidad e institución. Hacia una nueva moral sexual, en Selecciones de Teología, 131 (1994) p. 231. 
mirar con indiferencia. Todos sabemos lo que conlleva el llamado argumento teológico de la «recepción» a la hora de valorar una enseñanza eclesial. Cuando falta tal «recepción», la enseñanza por muy solemne que sea queda en agua de borrajas. No recibe, por así decirlo, el espaldarazo del pueblo de Dios. Esto es lo que está sucediendo con muchas o, al menos, varias de las enseñanzas oficiales de la iglesia. El magisterio sigue insistiendo machaconamente en ciertos temas y los creyentes hacen caso omiso de lo que dice.

Retomo el mensaje del autor citado. «Las diversas investigaciones psicosociológicas , tanto sobre el comportamiento sexual de la población en general como de los que se consideran a sí mismos como practicantes, no dejan lugar a dudas sobre la situación que comentamos. Los datos sobre el sentido de la evolución de los creyentes en torno a las cuestiones sexuales indican direcciones coincidentes en otros ámbitos culturales diferentes de España y tan diversos entre sí como pueden ser Estados Unidos o la católica Polonia (la nación católica donde más se practica el aborto y en donde -según datos de 1991- un 81 por ciento de la población se pronuncia en contra de la doctrina de la iglesia sobre anticonceptivos y un 71 por ciento en contra de la doctrina sobre al aborto).

La impresión general que se saca es plenamente coincidente con la que recibimos desde otro ángulo más reducido, pero más profundo: el de la observación clínica en el campo de la psicoterapia. Estamos ante un modo nuevo de pensar y de sentir la propia experiencia sexual.

El pensar y el sentir del discurso eclesiástico y el de la sociedad, en la cual este discurso se presenta con intención configurante, pertenecen a dos mundos, a dos sensibilidades, a dos modos de valorar radicalmente distintos. Más grave todavía. Si las estadísticas nos hablan de una progresiva transformación de valores y conductas sexuales, (entre católicos y no católicos), la relectura de un número de la revista Concilium, aparecido en 1974 y dedicado al tema La sexualidad en el catolicismo contemporáneo, nos demuestra que, después de veinte años, la posición de la iglesia respecto de los grandes temas que preocupan a la conciencia moral de los creyentes permanece siendo exactamente la misma e incluso se muestra con un carácter más represivo todavía en sus últimos pronunciamientos. Es el caso del nuevo Catecismo universal» ${ }^{47}$.

Me parece que lo dicho es más que suficiente para probar el tema de fondo: el distanciamiento e incluso el enfrentamiento que hay entre doctrina eclesial, aquí en el tema concreto de la sexualidad, pero extensible a otros muchos temas, y lo que acontece en el mundo. El diálogo, que el concilio

47. Ib. 232. 
Vaticano II propuso como camino a seguir entre iglesia y mundo, ha quedado muy deteriorado. Las instituciones eclesiales hablan un lenguaje inaceptable para el mundo de hoy. Las posturas se sitúan cada vez a mayor distancia. No parece que en el momento actual se está llevando a cabo lo que se proponía como enunciamiento de este apartado: dialogar con el mundo y no luchar contra el mundo. A la larga y a la corta, quien está por medio, el hombre, es el que sufre las consecuencias. Como creyente cristiano se ve afectado por decisiones magisteriales que le resultan inaceptables. No entiende cómo las instituciones superiores de la iglesia, que tanto blasonan de su cometido magisterial, sigan ofreciendo doctrinas y prácticas morales alejadas de lo que el hombre vive en la calle. Nota el distanciamiento entre lo que la iglesia dice por medio de sus jerarcas y lo que las instituciones sociales, de signo muy diverso, afirman. $\mathrm{Y}$, como la vida se impone siempre a la enseñanza que la desconoce, el cristiano termina por arrinconar lo que se le dice a nivel oficial y seguir los imperativos de la vida. ¿Es un capricho? ¿Una falta de obediencia a quienes afirman representar directamente al Señor?. Ni lo uno, ni lo otro. Por lo menos, en teoría. Puede darse una verdadera responsabilidad en quienes optan por el camino indicado. Lo que conduce a pensar que el problema está en otra parte. Se halla ciertamente en la fuente. Las instituciones eclesiales están en la obligación de ejercer un estilo de magisterio que conecte con las inquietudes que se viven en el mundo. El diálogo iglesia-mundo, que propuso el concilio Vaticano II, es el camino a seguir. La iglesia debe «auscultar, discernir e interpretar con la ayuda del Espíritu Santo las múltiples voces de nuestro tiempo».

Ahí está la tarea. Una tarea ineludible. Una tarea antecedente a la magna tarea de la nueva evangelización. De no cumplirla, la iglesia se condena a ser una voz que nadie o muy pocos escuchan. Y la nueva evangelización terminará por ser una frase bonita que no tendrá resultado alguno.

Benito Dominguez SANCHEZ, O.S.A. Estudio Teológico Agustiniano Valladolid 